\title{
A CASE FOR INCLUDING ECONOMIC, SOCIAL AND CULTURAL RIGHTS IN THE NEW ZEALAND BILL OF RIGHTS ACT 1990
}

\section{Joss Opie*}

Economic, social and cultural rights are fundamental human rights, but New Zealand domestic law does not recognise them as such. This article discusses some of the difficulties this omission creates for the protection of these rights, and critiques the reasons for not including them in the New Zealand Bill of Rights Act 1990. It argues that economic, social and cultural rights should have the same legal status in New Zealand as civil and political rights: that is, justiciable rights which are also directly relevant to statutory interpretation, and law and policy-making.

\section{INTRODUCTION}

When the New Zealand Bill of Rights Act 1990 (NZBORA) was enacted, economic, social and cultural rights (ESCR) were intentionally omitted from it. As a result, New Zealand domestic law does not recognise ESCR as freestanding, justiciable rights, and they have an unequal legal status to the civil and political rights (CPR) affirmed in the NZBORA. In this article, I argue that there is a need for greater legal protection for ESCR in New Zealand, and that the reasons which have been offered for denying ESCR an equal status to CPR are unconvincing. Accordingly, these rights should be incorporated into the NZBORA. ${ }^{1}$

* Joss Opie is a Senior Associate at Buddle Findlay Lawyers, Wellington. He holds a BA/LLB from Victoria University of Wellington and a LLM from the University of Toronto. This article is written in his personal capacity. He would like to thank Professor Bill Atkin, Dr Brian Opie, and an anonymous reviewer for their insightful and helpful comments on earlier drafts. Any errors or omissions are his.

1 For a more comprehensive analysis of the issues discussed in this article, together with comparative studies of the economic, social and cultural rights [ESCR] recognised in the Brazilian, South African and Finnish Constitutions and a version of the New Zealand Bill of Rights Act 1990 [NZBORA] amended to include a series of ESCR, see Joss Opie "Economic, Social and Cultural Rights in New Zealand: Their Current Status and the Need for Change" (LLM Thesis, University of Toronto, 2010) University of Toronto Research Repository <https://tspace.library.utoronto.ca>. 
For the purposes of this article, I define ESCR as the rights and corresponding obligations in the International Covenant on Economic, Social and Cultural Rights (ICESCR or the Covenant). ${ }^{2}$ These rights and obligations are binding on New Zealand under international law, as it is a State party to the Covenant. ${ }^{3}$

In Part II, I briefly summarise the principal ESCR. In Part III, I set out the reasons that ESCR were left out of the NZBORA and describe the differences in the domestic legal status of CPR and ESCR as a result of this omission. In Parts IV and V, I argue that the omission is significant, with reference to the regressive effects the social and economic reforms of the 1980s and 1990s had on people's enjoyment of ESCR, and the lack of any real ability to test the policies implemented as part of these reforms against human rights standards. In this regard, I also summarise and critique a 1996 High Court judgment, Lawson $v$ Housing New Zealand, ${ }^{4}$ to demonstrate the effect of rights such as the right to adequate housing not being recognised in domestic law, and to provide an example of the type of inquiry New Zealand courts could engage in if ESCR were justiciable. In Part VI, I critique the reasons for leaving ESCR out of the NZBORA.

\section{ESCR}

The ICESCR includes a broad range of rights and obligations. They are principally as follows.

\section{A Covenant Rights}

These rights include the right to freedom from discrimination in the exercise of the rights set out in the ICESCR; ${ }^{5}$ the equal right of men and women to enjoy the Covenant rights; ${ }^{6}$ the right to work $;^{7}$ certain trade union rights; ${ }^{8}$ the right to social security; ${ }^{9}$ the right to an adequate standard of

2 International Covenant on Economic, Social and Cultural Rights 993 UNTS 3 (opened for signature 19 December 1966, entered into force 3 January 1976) [ICESCR or the Covenant].

3 New Zealand ratified the ICESCR and the International Covenant on Civil and Political Rights (999 UNTS 171 (opened for signature 19 December 1966, entered into force 23 March 1976) [ICCPR]) on 28 December 1978.

4 Lawson v Housing New Zealand [1997] 2 NZLR 474 (HC) [Lawson v HNZ].

5 Article 2(2).

6 Article 3.

7 Articles 6 and 7. This right includes a right "of everyone to the opportunity to gain his living by work which he freely chooses or accepts", and a corresponding obligation on States parties to safeguard this right (for example, by providing protection against unfair deprivations of work, such as unjustifiable dismissal); and a right to "the enjoyment of just and favourable conditions of work", such as remuneration sufficient to provide all workers with "a decent living for themselves and their families", safe and healthy working conditions, and paid holidays. As the United Nations Committee on Economic, Social and Cultural Rights [CESCR] states in General Comment No 18 E/C.12/GC/18 (2006) at [6], the right does not include "an absolute and unconditional right to obtain employment." 
living, including adequate food, clothing and housing; ${ }^{10}$ the right to the enjoyment of the highest attainable standard of physical and mental health; ${ }^{11}$ the right to education; ${ }^{12}$ and various cultural and intellectual property rights. ${ }^{13}$ In addition, in art 10 the States parties recognise that "[t]he widest possible protection and assistance should be accorded to the family"; "[s]pecial protection should be accorded" to mothers for a period before and after childbirth; and "special measures of protection and assistance should be taken on behalf of" children and young persons.

\section{B State Party Obligations}

\section{Progressive realisation and unjustifiable retrogressive measures}

States parties do not have to guarantee most of the Covenant rights immediately and in full. ${ }^{14}$ Instead, they undertake to take steps, to the maximum of their available resources, ${ }^{15}$ to realise progressively rights such as the right to social security or the right to adequate housing, until full realisation is achieved. ${ }^{16}$

8 Article 8. These include the right of everyone to form trade unions and join a trade union of his or her choice, and the right to strike.

9 Article 9.

10 Article 11.

11 Article 12.

12 Article 13. This right includes an obligation on States parties to provide free primary education, and to introduce progressively free secondary and tertiary education.

13 Article 15.

14 ICESCR, art 2(1). There is a distinction in the Covenant between rights which States parties "recognize", such as the right to education, and rights which States parties "undertake to guarantee" or "undertake to ensure". The obligation of progressive realisation in art 2(1) applies to "recognized" rights, while all other rights which do not come within that category must be guaranteed immediately and in full. The latter rights include the right of self-determination in art 1; the art 2(2) guarantee of non-discrimination; the undertaking in art 2(3) "to ensure the equal right of men and women to the enjoyment" of the rights set out in the Covenant; and the undertaking to ensure the trade union rights set out in art 8. See Matthew CR Craven The International Covenant on Economic, Social, and Cultural Rights: A Perspective on its Development (Clarendon Press, Oxford, 1995) at 134; Michael J Dennis and David P Stewart "Justiciability of Economic, Social, and Cultural Rights: Should There Be an International Complaints Mechanism to Adjudicate the Rights to Food, Water, Housing, and Health?" (2004) 98 AJIL 462 at fn 158; and CESCR General Comment No 3 E/1991/23 (1990) at [1] and [2].

15 For an analysis of the nature of this obligation, see CESCR An Evaluation of the Obligation to Take Steps to the "Maximum of Available Resources" Under an Optional Protocol to the Covenant E/C.12/2007/1 (2007).

16 For an analysis of the meaning of "full realization", see Opie, above n 1, at 13-15. A State party that achieves full realisation of one or all of the recognised rights will continue to have duties under the Covenant. Principal amongst these will be the duties to respect and protect the right(s), not to retrogress unjustifiably and not to introduce unjustifiable limitations. 
The flipside of the duty of progressive realisation is the obligation not to take unjustifiable retrogressive measures (that is, measures which reduce the extent to which a right is enjoyed within a State party's jurisdiction), and otherwise not to limit unjustifiably the enjoyment of a Covenant right. ${ }^{17}$ Subject to justifiable retrogression and maximum available resources, and until full realisation is achieved, States parties are required to improve "conditions over time without backward movement of any kind - in what may be described as a form of 'ratchet effect'." 18

Pursuant to art 4 of the Covenant, a retrogressive measure will be unjustifiable unless it is determined by law, compatible with the nature of the right in question, and is for the purpose of promoting the general welfare in a democratic society. A retrogressive measure will also be unjustifiable unless the responsible State party can show that before adopting the measure it comprehensively examined all alternatives. ${ }^{19}$ The State party must also show that the measure is proportionate, meaning "that the least restrictive measures must be adopted when several types of limitations may be imposed." 20

Accordingly, a State party will breach the Covenant if it postpones full realisation of the Covenant rights indefinitely (for example, by taking one step forward, and two steps backwards), arbitrarily reduces the level at which ESCR are enjoyed in that State's jurisdiction, or limits the rights in a way which renders them meaningless. ${ }^{21}$

\section{Domestic legal recognition of ESCR}

The ICESCR does not oblige States parties to incorporate its provisions into domestic law or give the rights it recognises any particular legal status. ${ }^{22}$ However, as the United Nations Committee on Economic, Social and Cultural Rights (CESCR) ${ }^{23}$ has stated, "in many instances

17 These obligations are derived from arts 2(1) and 4 of the Covenant. For an analysis of the relationship between these articles, see Opie, above $n$ 1, at 16-21. Limitations or retrogressions affecting the rights in arts 8(1)(a) and 8(1)(c) are excluded from the ambit of art 4 because those rights have their own specific limitations provisions.

18 Craven, above n 14, at 131.

19 CESCR General Comment No 19 E/C.12/GC/19 (2008) at [42].

20 CESCR General Comment No 17 E/C.12/GC/17 (2006) at [23].

21 For further examples of the ways in which States parties may violate their obligations under the Covenant, see the Maastricht Guidelines on Violations of Economic, Social and Cultural Rights E/C.12/2000/13 (2000) at [14] and [15]; CESCR General Comment No 12 E/C.12/1999/5 (1999) at [19]; CESCR General Comment No 13 E/C.12/1999/10 (1999) at [59]; CESCR General Comment No 14 E/C.12/2000/4 (2000) at [46]-[52]; and CESCR General Comment No 19, above n 19, at [64] and [65].

22 Article 2(1) and CESCR General Comment No 9 E/C.12/1998/24 (1998) at [5].

23 The CESCR was established to assist the United Nations Economic and Social Council in monitoring State party compliance with ICESCR obligations: see Philip Alston "Out of the Abyss: The Challenges Confronting the New UN Committee on Economic, Social and Cultural Rights" (1987) 9 Hum Rts Q 332. 
legislation is highly desirable and in some cases may even be indispensable". ${ }^{24}$ Generally, "whenever a Covenant right cannot be made fully effective without some role for the judiciary, judicial remedies are necessary." 25

Further, while States parties have a discretion as to how they recognise ESCR in national law, "the means used should be appropriate in the sense of producing results which are consistent with the full discharge of its obligations by the State party". ${ }^{26}$ In deciding on how (or whether) to give the Covenant effect in domestic law, a State party should take account: ${ }^{27}$

... of the means which have proved to be most effective in the country concerned in ensuring the protection of other human rights. Where the means used to give effect to the Covenant ... differ significantly from those used in relation to other human rights treaties, there should be a compelling justification for this.

\section{WHY ESCR WERE LEFT OUT OF THE NZBORA AND THEIR UNEQUAL STATUS IN NEW ZEALAND LAW}

\section{A The Reasons for Omitting ESCR from the NZBORA}

The NZBORA was enacted in 1990, five years after Geoffrey Palmer (then the Minister of Justice and Attorney-General) presented a document entitled "A Bill of Rights for New Zealand: a White Paper" (White Paper) to Parliament. ${ }^{28}$ In the White Paper, which included a draft Bill, the recently elected Labour Government explained what it considered the Bill would do and why New Zealand needed it.

The central reasons advanced for the Bill were that fundamental rights and freedoms were insufficiently protected in New Zealand, particularly because of the lack of a written Constitution and of a second House of Parliament. It was argued that the Bill would guarantee these rights and freedoms and restrain the abuse of governmental power. The Bill would also educate New

24 CESCR General Comment No 3, above n 14, at [3]. In subsequent General Comments the CESCR has elaborated on this point and provided examples of certain rights or elements of those rights which it considers cannot be adequately protected in the absence of legislation. These include the right not to be arbitrarily evicted from one's home (an element of the right to housing) (CESCR General Comment No 7 E/1998/22 (1997) at [9]) and the right to work (CESCR General Comment No 18, above n 7, at [25]).

25 CESCR General Comment No 9, above n 22, at [9].

26 Ibid, at [5]. See also CESCR General Comment No 3, above n 14, at [5], where the CESCR "notes, for example, that the enjoyment of the rights recognized, without discrimination, will often be appropriately promoted, in part, through the provision of judicial or other effective remedies."

27 CESCR General Comment No 9, above n 22, at [7].

28 Geoffrey Palmer "A Bill of Rights for New Zealand: A White Paper" [1984-1985] 1 AJHR A6 ["White Paper"]. 
Zealanders about fundamental freedoms and be a source of inspiration. ${ }^{29}$ As proposed, the Bill was to have supreme law status and courts would have had the power under it to strike down legislation. ${ }^{30}$

While the Bill's preamble referred to New Zealand's ratification of the International Covenant on Civil and Political Rights (ICCPR), ${ }^{31}$ there was no reference to the ICESCR, and ESCR were intentionally omitted from the Bill. ${ }^{32}$ The reasons given for this in the White Paper were that while the Bill should "capture and protect the continuing essence of our constitutional and political system", it should not "attempt to capture (or more accurately to impose) a temporarily popular view of policy." ${ }^{33}$ CPR were seen as "value free", but ESCR were characterised as an attempt to "freeze into a special constitutional status substantive economic and social policies."34

Further, the CPR in the Bill were said to be "principally negative rights in that they impose a duty on the State to refrain from infringing them", as opposed to imposing "positive obligations on the State to do something." 35 Accordingly, courts would be able to enforce these rights. The positive nature of ESCR, on the other hand, meant that such rights were unenforceable. ${ }^{36}$ ESCR were instead "given effect to through other legislative and administrative action." 37

After its presentation in Parliament, the Bill was referred to the Justice and Law Reform Select Committee. In its final report, the Committee stated that a significant majority of the submissions it had received on the Bill were opposed to it being enacted as supreme law, on the basis that this

29 Ibid, at 5

30 Ibid, at 5 and 6.

31 As Palmer "White Paper", above n 28 stated at [10.10], "[t]he Bill of Rights does not incorporate or enact the Covenant but its provisions are consistent with it."

32 The NZBORA does affirm the right to freedom from discrimination on the grounds set out in the Human Rights Act 1993 [HRA] (s 19), the right to freedom of association (s 17) and certain minority rights (s 20). These rights can also be characterised as ESCR. However, they were included on the basis that they were civil and political rights [CPR].

33 Palmer "White Paper", above n 28, at [3.14].

34 Ibid, at [4.14]. This quotation is taken from the discussion in the White Paper regarding the Bill's role in "enhancing accountable and democratic government." There is no express reference to ESCR in this section, but taken with the earlier characterisation of ESCR as imposing "a temporary popular view of policy", the contrast being made in this section appears to be between CPR, which are defined as value-free with respect to economic and social policy, and ESCR, which are defined as attempting to lock in certain policies. Paragraph [4.14] is also cited in [4.28] as being one of the paragraphs of the White Paper that provides the reasons for not including "economic rights" in the Bill.

35 Palmer "White Paper", above n 28, at [10.179].

36 Ibid.

37 Ibid. 
would transfer too much power to unelected judges. ${ }^{38}$ Accordingly, while the Committee supported the concept of a Bill of Rights, it recommended that the Bill be enacted as an ordinary statute.

The Committee further stated: ${ }^{39}$

[F]undamental social and economic rights ... are obviously as important to New Zealanders as the civil and political rights in the White Paper draft ... . However, there are great difficulties in dealing with such rights in a judicially enforceable supreme law such as the White Paper draft. With a bill that is not judicially enforceable there are much fewer problems .... In Appendix A the Committee suggests that some of these major specified rights could be included. It is recognised that effective exercise of civil and political rights depends on securing an adequate standard of living, housing, health care and education.

While the Committee's recommendation that the Bill be enacted as an ordinary statute was ultimately accepted, the recommendation regarding ESCR was not. In Parliament, Palmer explained that this was because ESCR were in "a different category from civil and political rights": as in the White Paper, CPR were said to be concerned with restraining State power, while ESCR apparently

38 Justice and Law Reform Committee "Final Report of the Justice and Law Reform Committee on a White Paper on A Bill of Rights for New Zealand" [1988] AJHR I.8c at 2-3 ["Justice and Law Reform Committee Final Report"].

39 Ibid, at 4. The ESCR which the Committee suggested could be included were the right to an adequate standard of living, including food, housing and health care; the right to work; the right to education; the right to own property; and the right to participate in the cultural life of the community (at 10). It is not entirely clear, however, what status the Committee envisaged ESCR as having. It appears that the Committee considered that such rights would be more in the nature of directive principles, or that while ESCR could be justiciable to some degree, they would not have the same status as CPR. This is because while the excerpt from the Committee's report quoted above seems to suggest that the ESCR it recommended be included in the Bill would have an equal status to CPR, other sections from the report indicate otherwise. For example, in discussing what became the interpretative direction in s 6 of the NZBORA, the Committee only stated (at 10) that "[t]he Bill could include a provision ... directing that the interpretation of an enactment consistent with the civil and political rights in the bill is to be preferred ...." (emphasis added). The same distinction is made in the Committee's reference to the Attorney-General's responsibility to report on Bills inconsistent with the NZBORA: once again, there is an express reference to CPR only. This is despite the fact that the Committee recommended (at 5) that a reference to "social and economic rights" be included in the preamble to the Bill. However, the Committee also recommended (at 11) that a "Parliamentary select committee" be established "to examine bill of rights matters." It envisaged this select committee as having jurisdiction to review and report to Parliament not only on Bills but also on enactments that it considered to be inconsistent "with any of the rights in the bill" (that is, either CPR or ESCR) (emphasis added). The select committee would have had jurisdiction to carry out its review powers in respect of enactments either at "its own initiative or on receipt of a written complaint from a member of the public." It is not clear whether the Committee considered that the courts would have jurisdiction to adjudicate upon cases alleging ESCR breach. 
were not. Palmer also stated that the non-inclusion of ESCR did not mean that such rights were less important, "but, rather, that they should be protected in a different way." 40

In a book published in 1992, Palmer (who was by then Sir Geoffrey, having been knighted in 1991) stated that Caucus had vigorously debated the Committee's recommendation on ESCR, but that he: ${ }^{41}$

... successfully opposed such matters being included in the legislation because it would suggest such matters may be capable of judicial resolution. To broaden a Bill of Rights so that it encompassed such broad policy questions would have made it unmanageable in my view and opened it up to ridicule. It also seemed to me that to state as fundamental rights matters which it was not within the power of government to deliver would cause expectations to rise, only to be dashed. I do not doubt it should be the aim of the political system to deliver such things as far as practicable. I cannot see that in areas of policy quasi-legal guarantees help in the delivery.

Much later (in a paper he delivered in 2006), ${ }^{42}$ Palmer referred to an argument in favour of extending the NZBORA to include ESCR. ${ }^{43}$ He stated that South Africa was the principal model for such an approach, described some of the ways in which ESCR are recognised under the South African Constitution, and noted two of the South African Constitutional Court's leading ESCR judgments. ${ }^{44}$ Referring to those judgments as "bold", Palmer argued that such "judicial encroachment" into the prerogatives of the executive and legislature would be unacceptable in New Zealand, and that New Zealand's judges did not have the requisite "background or capacities" to adjudicate on "social policy". He considered that such issues were "best left to politics". 45

40 (10 October 1989) 502 NZPD 13040.

41 Geoffrey Palmer New Zealand's Constitution in Crisis: Reforming Our Political System (John McIndoe, Dunedin, 1992) at 57 [New Zealand's Constitution in Crisis].

42 Geoffrey Palmer "The Bill of Rights Fifteen Years On" (Keynote Speech for the Ministry of Justice Symposium on the New Zealand Bill of Rights Act 1990, Wellington, 10 February 2006) at [28]-[29] ["The Bill of Rights Fifteen Years On"].

43 See John Smillie "Who Wants Juristocracy?" (2006) 11 Otago L Rev 183 at 193-195.

44 Minister of Health and Others v Treatment Action Campaign and Others (No 2) [2002] 10 B Const LR 1033 (SA Const Ct) and Government of the Republic of South Africa v Grootboom and Others [2000] 11 B Const LR 1169 (SA Const Ct).

45 Palmer "The Bill of Rights Fifteen Years On", above n 42, at [27]-[29]. 


\section{B The Unequal Status of CPR and ESCR in Domestic Law}

\section{$1 C P R$}

As set out above, Parliament's intention in enacting the NZBORA was to give greater protection to CPR in New Zealand. Although the NZBORA is not supreme law, this objective has been achieved to a degree.

Importantly, the CPR affirmed in the NZBORA are directly relevant to statutory interpretation and law-making. Section 6 of the NZBORA provides that legislation must be interpreted consistently with the NZBORA where possible. Further, as well as the requirement in the Cabinet Manual that the rights in the NZBORA be considered during the legislative process, ${ }^{46} \mathrm{~s} 7$ of the NZBORA imposes a duty on the Attorney-General to report to Parliament where a Bill appears to be inconsistent with the NZBORA. As a result, the Ministry of Justice screens all proposed legislation for consistency with the CPR affirmed in the NZBORA. ${ }^{47}$

In addition, the rights in the NZBORA are justiciable. As well as having jurisdiction to award damages for breach of those rights and other remedies such as declarations, ${ }^{48}$ the courts may indicate that an ordinary enactment is inconsistent with the NZBORA. Such an indication does not require Parliament to remedy the inconsistency or give rise to a right to relief, but may be seen as imposing an obligation (of a political or moral nature) on Parliament to reconsider the legislation in question and justify any decision not to rectify it. ${ }^{49}$

46 See Cabinet Office Cabinet Manual 2008 at [7.60], which states that when a Minister seeks to include a Bill in the legislative programme of government, he or she must draw attention to any aspects of the Bill that may have implications for, or affect the rights in, the NZBORA, the HRA, or "international obligations". Further, when a Bill is submitted to the Cabinet Legislation Committee for approval for introduction to the House of Representatives, the Minister responsible must confirm that amongst other matters the Bill complies with the rights in the NZBORA and the HRA (at [7.61]).

47 Ibid, at [7.62].

48 See Simpson v Attorney-General [1994] 3 NZLR 667 (CA) and Taunoa v Attorney-General [2007] NZSC 70, [2008] 1 NZLR 429 [Taunoa]. There is no express remedies provision in the NZBORA. However, the courts have found they have an implicit jurisdiction to grant "appropriate and effective remedies where rights have been infringed" (see in this regard and for example Taunoa at [106]).

49 See, for example, Hansen v R [2007] NZSC 7, [2007] 3 NZLR 1 at [259], where McGrath J states:

As a result, it is to be expected that New Zealand courts from time to time will be constitutionally bound, applying s 4 of the Bill of Rights Act, to give effect to legislation which they have concluded is not capable of being read consistently with the Bill of Rights. In such instances it is the constitutional responsibility of the court to indicate in its judgment that it has relied on s 4 of the Bill of Rights Act to uphold an inconsistent provision in another statute. Other branches of government are under no obligation to change the law to remedy the inconsistency, but it may be expected that there will be a reconsideration by them of the inconsistent legislation. 
Proceedings under the Human Rights Act 1993 (HRA) ${ }^{50}$ may also be brought before the Human Rights Review Tribunal (HRRT) ${ }^{51}$ alleging that a public act, omission or enactment is inconsistent with the NZBORA's right to freedom from discrimination. If the HRRT finds an inconsistency, it may grant various remedies including damages (other than when the inconsistency arises as a result of an enactment). ${ }^{52}$ In the case of an enactment, the HRRT may only make a declaration of inconsistency. ${ }^{53}$ Such a declaration does not bind the Government, but the declaration must be reported to Parliament, along with advice on how the Government intends to respond to the declaration. ${ }^{54}$

\section{The NZBORA's effect}

Various commentators consider that the NZBORA has had not only an important impact in CPR cases, statutory interpretation and law-making, but also on policy. ${ }^{55}$ Palmer has contended that the statute has been "a set of navigation lights for the whole process of government to observe", and that it has led to more principled governance in New Zealand. ${ }^{56}$

See also Moonen v Film and Literature Board of Review [2000] 2 NZLR 9 (CA) at 17 per Tipping J. For a discussion of these "indications" and whether the courts have an implied jurisdiction under the NZBORA to issue a formal declaration of inconsistency (as opposed to simply indicating such inconsistency), see Claudia Geiringer "On a Road to Nowhere: Implied Declarations of Inconsistency and the New Zealand Bill of Rights Act" (2009) 40 VUWLR 613.

50 As the title to the HRA states, its purpose is to "consolidate and amend the Race Relations Act 1971 and the Human Rights Commission Act 1977 and to provide better protection of human rights in New Zealand in general accordance with United Nations Covenants or Conventions on Human Rights."

51 The HRRT is a first instance, semi-judicial tribunal continued by s 93 of the HRA.

52 HRA, s 92I.

53 Ibid, s 92J.

54 Ibid, s 92K.

55 See Palmer "The Bill of Rights Fifteen Years On", above n 42, at [14]-[20]; Andrew Butler and Petra Butler The New Zealand Bill of Rights Act: A Commentary (LexisNexis, Wellington, 2005) at ch 35; and Ivor Richardson "The New Zealand Bill of Rights: Experience and Potential, Including the Implications for Commerce" (2004) 10 Canterbury L Rev 259 at 262. For a contrary view in some respects, see Andrew Geddis "The Comparative Irrelevance of the NZBORA to Legislative Practice" (2009) 23 NZULR 465. Geddis, however, states at 469 that he accepts that the NZBORA has had an impact on diverse fields of New Zealand's law. Further, while Geddis states at 472 that it is "impossible to measure just how much of an impact the NZBORA vetting process actually has on the creation of the government's legislative proposals" as the development of government Bills "takes place inside something of a black box", he accepts that "it seems likely that the government will decide against bringing some legislative proposals before Parliament after being advised that they are NZBORA inconsistent."

56 Palmer "The Bill of Rights Fifteen Years On", above n 42, at [38]. 
In addition, the justiciability of the rights in the NZBORA (and HRA) has allowed the judiciary to apply them in concrete cases, and at the same time explain what those rights mean in the New Zealand context. This must have led to a greater understanding of those rights in New Zealand and to CPR having a higher profile in New Zealand than would otherwise have been the case.

\section{ESCR's Lesser Status}

(a) Consequences of the omission of ESCR from the NZBORA

Unlike CPR, in New Zealand domestic law there are no free-standing, generally justiciable ESCR. New Zealand law does not oblige the State to realise ESCR progressively, and it does not prohibit unjustifiable retrogressive measures in respect of ESCR or other unjustifiable limitations (other than limitations concerning the right to freedom from discrimination and of association, and the rights of ethnic, religious and linguistic minorities, and then only to the extent provided for in the NZBORA and HRA).

The courts' jurisdiction under the NZBORA to declare that public action is inconsistent with the rights affirmed in the NZBORA, and to indicate legislative inconsistency, does not extend to ESCR such as the right to health or the right to social security. The same applies to the HRRT's jurisdiction under the HRA, including its power to declare that an enactment is inconsistent with the NZBORA's right to freedom from discrimination.

Consequently, whether a certain law, policy or other public action has violated an individual's ESCR is justiciable domestically to a significantly lesser extent than alleged breaches of an individual's CPR. ${ }^{57}$

It also follows that because ESCR are not generally included in the NZBORA or the HRA, they have a much lesser effect on statutory interpretation, law-making, and policy than they otherwise would. For example, because the NZBORA does not affirm ESCR, those rights fall outside of the $\mathrm{s}$ 6 obligation to interpret statutes consistently with the NZBORA's rights where possible; and outside of the review that the Attorney-General conducts of each Bill in order to comply with $\mathrm{s} 7$ of the NZBORA. Further, while the Cabinet Manual requires that Ministers identify potential inconsistencies between Bills and "international obligations"58 (which include New Zealand's obligations under the ICESCR), there is little evidence that proposed legislation is analysed for compliance with ESCR. ${ }^{59}$

57 See also Claudia Geiringer and Matthew Palmer "Human Rights and Social Policy in New Zealand" (2007) 30 Social Policy Journal of New Zealand 12 at 37, who state that "it is clear that as a general proposition, [ESCR] currently receive substantially less judicial protection in New Zealand than do [CPR]."

58 Cabinet Office Cabinet Manual, above n 46, at [7.60(d)].

59 See Geiringer and Palmer, above n 57, at 33, who state: 


\section{(b) Recognition of aspects of ESCR: legislation and common law}

This is not to say that New Zealand legislation does not recognise ESCR at all. For example, the Minimum Wage Act 1983, the Health and Safety in Employment Act 1992, the Employment Relations Act 2000 and the Holidays Act 2003 protect elements of the right to work and the right to the enjoyment of just and favourable conditions of work. Legislation such as the New Zealand Public Health and Disability Act 2000 and the Accident Compensation Act 2001 promote the right to health (by, for example, providing for the public funding and provision of health and disability support services, and for compensation and other entitlements for specified personal injuries). Statutes such as the Housing Corporation Act 1974, the Housing Restructuring and Tenancy Matters Act 1992 and the Social Security Act 1964 are relevant to the right to an adequate standard of living (including the right to adequate housing) and the right to social security.

Also, aspects of the rights or entitlements that those and other statutes establish are justiciable in New Zealand courts. ${ }^{60}$ For example, an employee who alleges that he or she has been unjustifiably dismissed, disadvantaged or discriminated against may sue in the Employment Relations Authority or the Employment Court ${ }^{61}$ (or under the HRA in relation to discrimination, as discussed above) for a series of remedies including compensation. A person who alleges that he or she has not received an entitlement under the Accident Compensation Act in relation to a covered personal injury may appeal to the District Court (and subsequently to higher courts). ${ }^{62}$ In addition, the HRRT's jurisdiction referred to above in respect of the right to freedom from discrimination provides an indirect route for litigating ESCR. ${ }^{63}$

By requiring legislative proposals to confirm compliance with 'international obligations', [this mechanism] does have the potential to facilitate consideration of [ESCR]. Again, although further study is required, we suspect that this mechanism is not routinely used to analyse the implications of legislative proposals for [ESCR].

60 See also Geiringer and Palmer, above n 57, at 36, who state: "[t]he New Zealand statute books contain countless examples of the courts and/or quasi-judicial bodies being expressly empowered to protect and enforce specific aspects of [ESCR]." See further New Zealand's third periodic report under the ICESCR (Third periodic report submitted by States parties under articles 16 and 17 of the Covenant: New Zealand E/C.12/NZL/3 (2009) at [22]-[27]).

61 Employment Relations Act 2000, pt 9.

62 Accident Compensation Act 2001, pt 5. This right of appeal arises after a less formal review process of a decision to decline a claim for an entitlement has been conducted.

63 See, for example, Child Poverty Action Group Incorporated v Attorney-General HC Wellington CIV-2009404-273, 25 October 2011 [CPAG v AG]. In these proceedings, the Child Poverty Action Group sought a declaration that legislation providing for certain tax credits as part of a "Working for Families" (WFF) policy initiative gave rise to discrimination on the ground of employment status against people on income tested benefits (who were ineligible for the credits). While this case could be characterised as simply concerning a CPR, being the right to freedom from discrimination, it also concerns ESCR, such as the right to social security, the right to an adequate standard of living and the Covenant's own prohibition of 
Further, the common law provides certain means by which New Zealand's obligations under the ICESCR may be given some effect in domestic law. One of these is the administrative law requirement that decision-makers exercising a statutory power of decision take into account all relevant considerations. Where decisions which affect ESCR are being made, the obligations set out in the Covenant are likely to be such considerations. The requirement to take these obligations into account may influence decision-making, and a failure to do so by a decision-maker may provide grounds for challenging his or her decision. Also, the common law presumption of statutory construction that, where possible, statutes should be interpreted consistently with New Zealand's international obligations, could be relied upon to argue in favour of ESCR-consistent interpretations of legislation which affect these rights. In Part VI below, I analyse these two mechanisms in more detail.

However, the legislative recognition of aspects of ESCR referred to above is piecemeal. Also, for the reasons set out in Part VI, any additional protection that the common law mechanisms may provide for ESCR is likely to be limited, and in any case is indirect. The critical difference between CPR and ESCR in New Zealand domestic law is that the law does not recognise ESCR themselves as fundamental, justiciable rights. As Geiringer and Palmer state, "[w]hat the New Zealand courts lack is the ability to test state and/or private action against broad [ESCR] protections". ${ }^{64}$

discrimination. The High Court held that the WFF initiative did not subject the vast majority of beneficiaries to any prohibited discrimination (and that even if it did, such discrimination was justified in terms of $s 5$ of the NZBORA). It also held that while a subset of beneficiaries were discriminated against as a result of the WFF initiative, that discrimination was justifiable. See also Ministry of Health $v$ Atkinson (2010) 9 HRNZ 47 (HC), in which the High Court dismissed the Ministry's appeal against a HRRT declaration that the Ministry's practice of excluding specified family members from payment for the provision of funded disability support was inconsistent with the right to freedom from discrimination on the grounds of family status; and was not a justified limitation of that right in terms of s 5 of the NZBORA. This judgment has since been affirmed by the Court of Appeal: Ministry of Health $v$ Atkinson [2012] NZCA 184.

64 Geiringer and Palmer, above n 57, at 36. See also Butler and Butler, above n 55, who note at [35.12.4]:

Since the enactment of [the NZBORA], there has been continued pressure by interested persons and organisations to secure the inclusion of at least some [ESCR] in BORA or some other free-standing legislation.

The authors further note a submission by the New Zealand Human Rights Commission to the Constitutional Arrangements Committee [CAC] in 2005 recommending amongst other matters that the CAC investigate "the examples provided by overseas constitutions for the inclusion of [ESCR] in any future constitutional document". As the authors state, however, the CAC "did not specifically pick up this recommendation." 


\section{Do These Differences Matter?}

Accordingly, Parliament has intentionally given ESCR a lesser legal status than CPR. But does this matter? The Government's position is that it does not: in its view, ESCR are adequately protected by other means. ${ }^{65}$ In the next two Parts, I argue that this view is incorrect.

\section{SOCIAL REVOLUTION AND APPARENT ESCR VIOLATIONS}

As stated above, the NZBORA was promoted on the basis that CPR were insufficiently protected in New Zealand. However, there was no fear when the White Paper was presented to Parliament in 1985 that CPR were in significant danger. The White Paper stated that "[n]o Government and no Parliament we are likely to have in New Zealand in the foreseeable future are going to attempt to sweep away basic rights."66 Instead, it was argued that there was a need to protect against incremental erosion of CPR and to put in place "safe systems" before any emergency arose. ${ }^{67}$

It was no doubt correct in 1985 that CPR were not under any real threat in New Zealand. The same could not be said for ESCR.

65 See, for example, New Zealand's initial periodic report under the Covenant (Initial reports submitted by States parties under articles 16 and 17 of the Covenant: New Zealand E/1990/5/Add.5 (1991) at [6]), in which New Zealand advised that:

After discussion of the issues involved, it was decided not to extend the terms of the proposed Bill [for the NZBORA] to include social and economic rights. The enjoyment of these rights, it was felt, is already adequately protected under the wide range of specific laws by which the Government is committed to positive action for their promotion.

See also Second periodic reports by States parties under articles 16 and 17 of the Covenant: New Zealand E/1990/6/Add.33 (2001) at [48(a)], which states:

The Government decided against the inclusion of economic, social and cultural rights in the New Zealand Bill of Rights Act 1990 on the basis that such rights are implemented through other legislation and administration, and the common law.

[I]t is considered that the present systems in New Zealand provide an appropriate level of protection to fulfil, in practice, New Zealand's obligations under the Covenant.

66 Palmer "White Paper", above n 28, at [4.8]. The parliamentary debates on the Bill also reflect this sentiment: see for example (10 October 1989) 502 NZPD 13050-13051.

67 Palmer "White Paper", above n 28, at [4.10] and [4.24]. 


\section{A The Social Revolution}

On 11 June 1984, the Labour Party was elected to Government, replacing the National Government then in power. ${ }^{68}$ At the time, public sector debt, inflation and unemployment were all rising in New Zealand, and a currency crisis created additional instability. ${ }^{69}$ Changes in economic and social policy were necessary.

The Labour Government, however, went well beyond moderate reform. Instead, it carried out radical neoliberal ${ }^{70}$ reforms of New Zealand's State institutions and its economy, at great speed. ${ }^{71}$ The National Government continued this agenda following its election in 1990. In 1993, The Economist described these reforms as "more radical than any other industrial country's". ${ }^{72}$ In New Zealand, the period was referred to by some as one of revolution. ${ }^{73}$

\section{B Retrogressive Reforms}

At the time, and now, there was considerable debate about whether such drastic reforms were required and would be (or have been) beneficial in the long term. However, it seems clear that the reforms were retrogressive in terms of the extent to which ESCR were realised in New Zealand in 1984 in relation to, for example, the rights to work, to social security, to an adequate standard of living including adequate food, clothing and housing, and to education. The following statistics (which are not exhaustive by any means) evidence this retrogression. ${ }^{74}$

68 The Labour party had traditionally been a progressive, left-leaning party. National was traditionally conservative and right-leaning.

69 Jane Kelsey The New Zealand Experiment: a World Model for Structural Adjustment? (Auckland University Press, Auckland, 1997) at 24 and 29-30. See also Paul Dalziel "National's Macroeconomic Policy" in Jonathan Boston and Paul Dalziel (eds) The Decent Society? Essays in Response to National's Economic and Social Policies (Oxford University Press, Auckland, 1992) 19 at 20.

70 Kelsey, above n 69, at 2, describes the reform agenda as being based around the fundamentals of "market liberalisation and free trade, limited government, a narrow monetarist policy, a deregulated labour market, and fiscal restraint".

71 Ibid, at 33. See also Tim Hazledine and John Quiggan "No More Free Beer Tomorrow? Economic Policy and Outcomes in Australia and New Zealand since 1984" (2006) 41 Australian Journal of Political Science 145 at 152, who state:

The speed with which the reform program was implemented is truly astounding. Of the 104 reforms listed by Bollard, Lattimore and Silverstone (1996) between 1984 and 1991, 65 were completed or well underway by the end of 1988.

72 The Economist (16 October 1993) at 20, cited in Kelsey, above n 69, at 8.

73 Kelsey, above n 69, at 323. See also Hazledine and Quiggan, above n 71, at 152.

74 For a full account, see Kelsey, above n 69. See also the Concluding observations of the Committee on Economic, Social and Cultural Rights: New Zealand E/C.12/1993/13 (1994) at [11], where the CESCR 
In the 1960s, full employment was "the central plank of economic and social policy." 75 However, after 1984, "the goal of full paid employment ... was treated by policymakers as unattainable, unaffordable and undesirable." ${ }^{76}$ Unemployment in the general population, seen as the natural consequence of a dynamic economy, ${ }^{77}$ rose from 3.8 per cent in 1985 to 7.7 per cent in 1990 and to 11.1 per cent in $1991 .^{78}$

Figures for Māori and Pacific Islanders were much worse. This was largely due to heavy Māori and Pacific Island dependency on unskilled wage labour, which the State had traditionally provided. When that work was cut back dramatically, Māori and Pacific Islanders suffered disproportionately and severely. ${ }^{79}$ Referring to June 1991 figures, Dalziel states: ${ }^{80}$

The Household Labour Force survey unemployment rate for Māori was 27.1 per cent (the European rate was 7.7 per cent; the Polynesian rate was 28.6 per cent). It is not easy to imagine what having more than one in four workers unemployed does to a community, but for comparison, note that at the height of the Great Depression, the United States unemployment rate peaked at just under 25 per cent in 1933. That experience seared the psyche of the whole nation, and led to a range of institutional and policy reforms to prevent its recurrence.

Income inequality grew, as did poverty. ${ }^{81}$ Between 1989 and 1992, "the number of New Zealanders estimated to be living below the [unofficial] poverty line rose by at least 35 percent." 82 As the number of people on benefits grew (almost doubling between 1984 and 1990), the value of benefits was reduced. ${ }^{83}$ In December 1990, the National Government announced "core benefit rate cuts of up to 25 per cent and tighter welfare eligibility rules [which] removed $\$ 1.275$ billion from the social welfare budget in a full fiscal year". ${ }^{84}$ The Government implemented these changes

noted that "restrictive economic and social policies" then in place had affected "the realization of economic, social and cultural rights, particularly of the most vulnerable groups of society."

75 Kelsey, above n 69, at 24.

76 Ibid, at 259.

77 Ibid, at 173.

78 Ibid, at 260. By 1994, unemployment had dropped back to 9.5 per cent.

79 Ibid, at 283-284.

80 Dalziel, above n 69, at 21.

81 Kelsey, above n 69, at 271.

82 Ibid, at 10.

83 Ibid, at 273 and 279.

84 Dalziel, above n 69, at 19 and 32. According to Bob Stephens ("Budgeting with the Benefit Cuts" in Jonathan Boston and Paul Dalziel (eds) The Decent Society? Essays in Response to National's Economic 
despite advice that they would cause financial hardship and could intensify the economic recession then being experienced due to their impact on incomes and consumption. ${ }^{85}$ This impact was considerable, as "[b]eneficiaries in the bottom 20 percent [in terms of household income across the country] experienced a reduction of between 13 and 30 percent of disposable income." 86

Substantial cuts in education (\$380 million) and health (\$192 million) were also implemented. ${ }^{87}$

In addition, the Government began to charge for services which it had previously provided for free, or to increase charges. This included fees for tertiary education, which were raised significantly in $1990 .{ }^{88}$ A result of this was reflected in New Zealand's second periodic report under the ICESCR, which referred to concern: 89

... that young people are emerging from the tertiary sector with high levels of debt. It has been argued that this high level of debt is contributing to high emigration levels of young graduates as wages in New

Zealand are not sufficiently high to assist in student loan debt repayments.

A considerable increase in social distress became evident. Between 1974 and 1990 the rate of male suicide rose by 288 per cent, "with the greatest increase in the late 1980s."90 Between 1991 and 1993, the Salvation Army registered a 1,117 per cent rise in the use of its food parcel service. ${ }^{91}$ Boston and Dalziel, writing in 1992, stated that "large numbers of disadvantaged New Zealanders [were having to] rely on voluntary agencies to satisfy their basic food and clothing needs",92 something which they considered was unnecessary, and morally and socially unacceptable. They

and Social Policies (Oxford University Press, Auckland, 1992) 100 at 106 and 109), the tighter eligibility conditions for benefits generally came into effect from March 1991, while the cuts were implemented from 1 April 1991.

85 Stephens, above n 84, at 110-111. See also Dalziel, above n 69, at 32-33.

86 Kelsey, above $n$ 69, at 277.

87 Chris Rudd "Controlling and Restructuring Public Expenditure" in Jonathan Boston and Paul Dalziel (eds) The Decent Society? Essays in Response to National's Economic and Social Policies (Oxford University Press, Auckland, 1992) 39 at 39.

88 Initial reports submitted by States parties under articles 16 and 17 of the Covenant: New Zealand, above n 65 , at [656].

89 Second periodic reports by States parties under articles 16 and 17 of the Covenant: New Zealand, above n 65 , at [570].

90 Kelsey, above n 69, at 295.

91 Ibid, at 292.

92 Jonathan Boston and Paul Dalziel (eds) The Decent Society? Essays in Response to National's Economic and Social Policies (Oxford University Press, Auckland, 1992) i at ix. 
further recorded that "not since the Great Depression has New Zealand witnessed such evidence of social deprivation and hopelessness, nor such high levels of unemployment."93

\section{A Lack of Evidence-Based Policy}

In a range of areas, ideology rather than evidence seemed to be the significant driver in policymaking. For example, writing in regard to the National Government elected in 1990, Boston and Dalziel considered that: ${ }^{94}$

... it appears that at least in some instances (e.g. housing and health care), decisions have been influenced too much by elegant, yet unproven, theories and too little by well-established practice or carefully designed experiments.

In Boston's view, some of the "radical changes" in areas such as income support, health care, housing, and tertiary education were "founded neither on sound theory nor on sound empirical evidence." 95

\section{Lack of an Accountability Mechanism}

Theoretically, the principal way in which the Governments could be held accountable by those who disagreed with the reforms was through the ballot box. However, the 1980s and 1990s saw the failure of parliamentary democracy in New Zealand, with the parties in Government repeatedly breaking election promises. ${ }^{96}$

93 At viii.

94 At $\mathrm{x}$.

95 Jonathan Boston "Redesigning New Zealand's Welfare State" in Jonathan Boston and Paul Dalziel (eds) The Decent Society? Essays in Response to National's Economic and Social Policies (Oxford University Press, Auckland, 1992) 1 at 16. See also Kelsey, above n 69, at 277-278.

96 See Kelsey, above n 69, at 37-38, 41 and 297-303 in relation to the 1984-1990 Labour Government:

[Labour] had promised to maintain social services, but it cut them. It had promised to retain state assets, but it sold them. It had promised full employment, but it produced record unemployment. It had promised constitutional government and the rule of law, but it circumvented, overrode and treated with contempt the democratic processes of representation, participation and accountability.

See Boston and Dalziel, above n 92, at $\mathrm{x}-\mathrm{xi}$ in relation to the National Government that took over from Labour:

Having won the 1990 election with an unprecedented majority, by late September 1991 public support for the Government (as measured by national opinion polls) had shrunk to just over 20 per cent-lower in fact than that enjoyed by the fourth Labour Government in the months leading up to the 1990 election. The reasons for this rapid collapse in National's support are readily apparent. They include the party's failure to keep its election promises (especially with respect to superannuation, health care, and tertiary education), its failure to signal its radical policy agenda prior to the election, the lack of public consultation on the 
This, and the severe consequences of the reforms for significant sectors of the population, led to "deep-seated scepticism about electoral politics and parliamentary democracy". ${ }^{97}$ In 1993, following a national referendum, the electoral system was changed from First Past the Post to a Mixed Member Proportional system. One of the main reasons for this was to reduce the likelihood of one of the two major parties being able to govern alone. In other words, its purpose was to place a restraint on State power, which many considered had been abused by Labour and National. ${ }^{98}$

Accordingly, both before and after the NZBORA's enactment, the purpose of which is "to affirm, protect, and promote human rights and fundamental freedoms in New Zealand", 99 a series of retrogressive measures were taken which directly impacted upon the levels of realisation of New Zealanders' internationally recognised ESCR. However, the lack of free-standing ESCR in New Zealand law meant that there was little scope for challenging any of the reforms on a legal basis, despite the fundamental human rights interests at stake.

The High Court's decision in Lawson $v$ Housing New Zealand, which I now discuss, provides a useful example of this lacuna in New Zealand law and its effect. ${ }^{100}$

nature of changes to be introduced, serious doubts about the merits of many of the planned changes, and the incompetence demonstrated in the handling of crucial issues such as superannuation and health care.

97 Kelsey, above n 69, at 297.

98 It is also not clear that the reforms produced their promised benefits. For example, Kelsey, above n 69, at 9, states that "between 1985 and 1992 total growth across OECD countries averaged 20 percent; New Zealand's economy shrank by 1 percent over the same period." In a 2006 comparison between the economic performance of Australia and New Zealand since 1984 (Hazledine and Quiggan, above n 71, at 145), the authors find that:

[F]rom quite similar starting points the two countries pursued liberal reform programs that differed sharply ... . Australia followed a more cautious, piecemeal, consensus-based approach, whereas New Zealand, in contrast, adopted a radical, rapid, 'purist' platform. The NZ reform package was generally seen by contemporary commentators as representing a 'textbook' model for best practice reform. However, Australia since 1984 has performed much better than New Zealand, whose per capita GDP growth indeed ranked at or near the bottom of the OECD.

Of course, the global economy over some of this period was volatile, particularly following the 1987 stock market crash. However, given that all OECD countries were subject to this volatility, it does not explain New Zealand's poor performance relative to other OECD members. For an opposing view, see Roger Kerr "No Time to Stop and Smell the Roses" The New Zealand Herald (online ed, Auckland, 15 March 2005) cited in Hazledine and Quiggan, above n 71, at 150.

99 NZBORA, long title.

100 Lawson $v$ Housing New Zealand and the Minister of Housing and the Minister of Finance HC Auckland M.538/94, 29 October 1996 [Lawson, unreported judgment]; and Lawson v HNZ, above $\mathrm{n} 4$. I refer to both the unreported and reported judgments, as the reported judgment omits sections of the unreported judgment relevant to my analysis. 


\section{$E$ Lawson v Housing New Zealand}

In this case, Mrs Lawson, a state housing tenant, sought judicial review of a series of decisions relating to the transfer of "state houses"101 to a company, Housing New Zealand Limited (HNZ), and the increase of the rent for those houses from subsidised to market rents. These reforms were implemented over a four year period beginning in 1991.

\section{The reasons for the reforms}

Prior to the reforms, rent subsidies for state house tenants were on average three times more than the assistance available to low-income private sector tenants. The Government considered that this was inequitable. Further, it was concerned that tenants could remain in state houses even if their financial situation improved. This was an issue because there was a significant waiting list for state houses, and on that list were people classified as being in "serious housing need" (that is, living in substandard or overcrowded housing, temporary accommodation, or housing costing over 50 per cent of their income). ${ }^{102}$ Access to adequate housing was also complicated by high private rents and high mortgage interest. ${ }^{103}$

To address this situation, the Government decided to eliminate rental subsidies for state houses (that is, move to market rents), and decided instead to provide assistance through an accommodation supplement which would vary according to factors such as family size, income and locality. The subsidy would be set at a level to incentivise (or force) each tenant "to seek the most cost-effective accommodation"104 (for example, so that tenants without families but living in larger houses would move to smaller houses, freeing up those houses for other tenants with families).

The principles informing the reforms included self-reliance, efficiency and greater personal choice. ${ }^{105}$ However, while funding cuts in health, education and social welfare had occurred in the 1991 budget, the Minister of Housing deposed that the Government was not aiming for fiscal savings through the housing reforms, but rather the improvement of "efficiency and fairness". ${ }^{106}$

Prior to the reforms' implementation, the Government was advised that the introduction of market rents would lead to a "major deterioration" in the living standards of many state house

101 "State house" is the term generally used in New Zealand to refer to a house built and/or owned by the New Zealand State and rented to people on lower incomes as a form of social assistance. See further Lawson, unreported judgment, above $\mathrm{n} 100$, at 3 and 5 .

102 Lawson, unreported judgment, above n 100, at 7.

103 Ibid, at 5 .

104 Ibid, at 9.

105 Ibid, at 6 .

106 Ibid, at 16 . 
tenants. ${ }^{107}$ The Government was also advised that many would have only a limited ability to change their accommodation (apparently due in part to an inadequate supply of low-cost housing, particularly one-bedroom units). Various strategies for easing the reforms' impact were recommended. They included staggered rent increases due to problems such as an insufficient supply of smaller units for tenants who could no longer afford their previous accommodation as a result of the increases, moving progressively rather than immediately to market rents, and reassessment of tenants during the introductory phase to determine which tenants required additional assistance. Most of these strategies were adopted. From the information available in the judgment, however, it appears that by 1995 HNZ had raised the rents of Mrs Lawson and most other state tenants to market levels. ${ }^{108}$

\section{The Lawsons and Mrs Lawson's application for review}

Mrs Lawson and her husband were elderly and her husband was in poor health. They had occupied the same state house in Onehunga, an Auckland suburb, for 49 years. As a result of the reforms, the rent payable by the Lawsons progressively increased from $\$ 81$ per week in 1992 to a total of \$165 per week in 1995 (an increase of just over 100 per cent). They were unable to pay the increased rate and, according to Mrs Lawson, alternative accommodation in the same area was only available at a higher rate. The Lawsons joined a rent strike, and HNZ ultimately sought to terminate their tenancy. Mrs Lawson then brought the application for review.

Mrs Lawson pleaded, amongst other matters, that HNZ's decision to move to market rents breached her right to life (affirmed in s 8 of the NZBORA). She further alleged that, in setting the Government's social objectives for 1993 and 1994, and in not ensuring that HNZ charged affordable rents, the Ministers of Housing and Finance failed to have proper regard to her right to life and to New Zealand's international obligations, including its obligations under the ICESCR.

\section{The High Court judgment}

Williams J dismissed Mrs Lawson's application. The judge found that HNZ's decision to impose market rents was not amenable to judicial review. There was no evidence of fraud, corruption or bad faith, and HNZ's decision did not breach the Housing Restructuring Act 1992 (HR Act), the legislative vehicle for the housing reforms. According to Williams J, the decision to increase rents was "purely commercial". 109

The Judge further considered that if HNZ's decisions on rents were reviewable, it would be placed at a competitive disadvantage as against private landlords. ${ }^{110}$ The implication of Mrs

107 Ibid, at 9.

108 Ibid, at 36 and 37.

109 Lawson v HNZ, above n 4, at 485.

110 At 486 
Lawson's claim was that HNZ may have to charge less than the market could bear, while private landlords were not so restricted. If this were the case, HNZ's ability to operate as a successful business would be affected and the market distorted. ${ }^{111}$ Williams J also held that Mrs Lawson's complaint was that her rent had been increased, not that HNZ had failed to follow a necessary procedural step in making that increase. Accordingly, her claim concerned the merits of HNZ's decision rather than the process by which it was made. This meant that it was outside the legitimate scope of judicial review. ${ }^{112}$

Williams J then turned to Mrs Lawson's claims against the Ministers. The Judge stated that the housing of lower income New Zealanders involved complex issues and was an area in which political judgements on the allocation of economic and social resources were required. Given this, in the absence of manifest unfairness relating to the procedure by which decisions about social housing were made, the Court would be less inclined to intervene. In Mrs Lawson's case, there was no procedural impropriety or inherent unfairness. Although Williams J recognised that the reforms had had "a seriously adverse effect on [Mrs Lawson's] financial position and on those who are similarly situated",113 the Judge also found that "any hardship which she experienced is insusceptible to judicial review." 114

In relation to Mrs Lawson's claim regarding the right to life, Williams $\mathrm{J}$ found that "an unduly strained interpretation" of the right would be required for it to apply to Mrs Lawson's circumstances. ${ }^{115}$ Further, even if the right were applicable, the Judge held that the reforms constituted a reasonable limit on the right under s 5 of the NZBORA, noting that "the provision of subsidised rental housing is no longer regarded as being as important in the public interest as was formerly the case." ${ }^{116} \mathrm{HNZ}$ could not, according to the Judge, be expected to tailor its policies to each tenant's specific circumstances.

The Judge also dismissed Mrs Lawson's allegation that the Ministers had not given proper regard to relevant international obligations. Williams J held: ${ }^{117}$

[I]t is not for this Court to judge whether the government of New Zealand has fully complied with those

obligations. It is sufficient for this Court to reach the view that the government has plainly made efforts

111 Ibid.

112 Ibid.

113 Lawson, unreported judgment, above n 100, at 48.

114 Lawson $v$ HNZ, above n 4, at 487.

115 At 495 .

116 At 495-496.

117 At 498-499. 
to balance the competing factors. Those efforts include the lengthy and detailed consideration of affordability and impact on living standards appearing in the reports earlier detailed and the changes to the accommodation benefit which accompanied them .... . Whether New Zealand has fulfilled its international obligations is a matter on which it may be judged in international forums but not in this Court. ...

Though the shareholding Ministers do not say that they expressly took the international instruments into account, the aims of the international instruments are comparable with the principles which underpinned the housing reforms and informed their formulation and implementation.

\section{THE ROLE ESCR COULD HAVE PLAYED}

In this Part, I consider the role that justiciable ESCR could have played in the context of the neoliberal reforms, specifically in Lawson $v$ Housing New Zealand and also more generally.

\section{A Lawson v Housing New Zealand}

As Williams J pointed out, Mrs Lawson's claim was concerned with the effect of the increase to market rents on her and her husband's standard of living, and particularly on their housing. However, New Zealand law provided no express legal basis for an adjudication of that claim on its merits (that is, an inquiry into the consistency of the move to market rents with Mrs Lawson's internationally recognised legal interest, the right to adequate housing).

If there had been a right to adequate housing (as set out in the ICESCR, including the prohibition against unjustifiable retrogressive measures) in the NZBORA or in other domestic legislation, the nature of the Court's inquiry would have been different. Critically, the Court would have had an express jurisdiction to determine whether HNZ's or the Ministers' decisions breached that right. I discuss below some of the issues that would have been justiciable if Mrs Lawson had been able to rely directly on such a right.

\section{Retrogressive measure}

The move to market rents constituted a retrogressive measure in relation to the right to adequate housing of numerous state tenants, and one which was apparently deliberate. As stated above, the Government knew that the reforms would result in a "major deterioration" in the living standards of many tenants. ${ }^{118}$ It was also advised before the reforms were implemented that "the most significant losers" would be current tenants. ${ }^{119}$

That being the case, in accordance with the right to adequate housing as defined in the ICESCR (including the extent of permissible limitations), such a retrogressive measure had, amongst other

118 Lawson, unreported judgment, above n 100, at 9.

119 Ibid, at 11. 
requirements, to be determined by law and not be incompatible with the nature of the right. Further, the Government was obliged to consider carefully all alternatives to that retrogression before implementing it, and to choose the least restrictive option available.

If Mrs Lawson had been able to plead such a right before Williams J, the Court would have been required to examine whether the Government complied with these obligations. Such an inquiry could well have been significant.

\section{Determined by law?}

It is arguable that the move to market rents was not determined by law. Williams $\mathrm{J}$ found that nothing in the HR Act required HNZ to increase rents to market rates. ${ }^{120}$ Rather, the Government made the initial decision to increase rents as part of its 1991 Budget, and HNZ implemented the first two staggered increases as the Government's agent. HNZ then made the remaining increases up to market rates independently from Government, but knowing that the Government wanted it to do this.

Williams J, however, held that the increases were "prescribed by law" in terms of s 5 of the NZBORA by applying a "pragmatic approach". ${ }^{121}$ The Judge apparently considered that while not specifically legislated for, it was within HNZ's discretion to make the increases given its obligation under s 4 of the HR Act to "operate as a successful business". Earlier in the judgment, Williams J had stated that: ${ }^{122}$

... [HNZ's] decision to shift the rents for its houses to market rent and the means by which that was done, was a matter which lay within the discretion of the board acting in accordance with its statutory obligations and within the given objectives. ... [HNZ] had the obligation to comply with its statute and the Crown's social objectives but it had the right, within that circumscribed field, to decide how to act.

The finding that the increases were prescribed by law is questionable in light of the Judge's conclusion that the HR Act "does not refer to rent levels". ${ }^{123}$ That being the case, it is difficult to argue that the move to market rents was either "determined" or "prescribed" by the HR Act. The finding is also questionable given that, as well as obliging HNZ to operate as a successful business, s 4 of the HR Act required the company to "assist in meeting the Crown's social objectives by

120 Lawson $v$ HNZ, above n 4, at 484.

121 Ibid, at 496. There is an issue about whether the phrases "determined by law" (the wording used in art 4 of the ICESCR) and "prescribed by law" (the wording used in s 5 of the NZBORA) have the same meaning. For the purposes of this analysis, however, I assume that there is no significant difference between the two.

122 Lawson $v$ HNZ, above n 4, at 485. Section 4(1) of the Housing Restructuring Act 1992 [HR Act] provided: "The principal objective of [HNZ] shall be to operate as a successful business that will assist in meeting the Crown's social objectives by providing housing and related services".

123 Lawson v HNZ, above n 4, at 485. 
providing housing". These "social objectives" included assisting "those on low incomes to obtain adequate and affordable accommodation" and that "[a]ccess to housing was not to be limited by personal factors including income." ${ }^{124}$ While Williams J considered that the rent increases were not inconsistent with these social objectives, ${ }^{125}$ this conclusion seems at odds with the Judge's finding that there was little doubt that the introduction of market rents had "a seriously adverse effect on [Mrs Lawson's] financial position and those who are similarly situated" ${ }^{126}$ and that the measures taken to ameliorate the impact of the new regime "have not come anywhere near fully compensating her for the increases in rent". ${ }^{127}$ It also appears at odds with the lack of a finding by the Judge against Mrs Lawson's contention that the charging of market rents had "resulted in her having inadequate housing". ${ }^{128}$

Therefore, not only was there no express legislative direction that HNZ should increase rents to market rates, but (and as discussed in more detail below) those increases were arguably inconsistent with the social objectives that the HR Act obliged HNZ to assist in meeting.

\section{Alternatives considered?}

As well as the increases arguably not being determined by law, there is nothing in the judgment to indicate that the Government carefully considered all other alternatives to its policy before implementing it. For example, nothing is said about whether the Government considered providing at least some additional housing itself to meet the demand (and why it rejected that option); whether it considered less drastic options, such as requiring tenants who had large state houses to move to smaller ones if, for example, those tenants' families were no longer living with them; or whether it considered persisting with less severe measures that were already being undertaken prior to the reforms, such as requiring tenants who could pay market rates to do so. ${ }^{129}$ Alternative policy options existed, and the Government was not forced to move quickly because of, for example, resource limitations. As set out above, the reforms were not designed to produce savings.

124 Ibid, at 484 .

125 Ibid, at 496.

126 Lawson, unreported judgment, above n 100, at 48.

127 Ibid, at 49 .

128 Lawson $v$ HNZ, above $\mathrm{n} 4$, at 479.

129 See the Initial reports submitted by States parties under articles 16 and 17 of the Covenant: New Zealand, above $\mathrm{n} 65$, at [430], which states:

Where tenants are able to pay market rates, they are charged accordingly. As at 31 March 1989, about 7 per cent of the Corporation's tenants were paying market rates. The majority, however, are charged at a lower rate in accordance with their income.

This report was before Williams $\mathrm{J}$ in Lawson $v$ HNZ, above $\mathrm{n} 4$. 
Had the Government's consideration of alternatives been an issue in the proceedings, different evidence may have been led. However, it does appear from the judgment that the Government decided on the policy of moving to market rates, and that the evaluation after that point was exclusively concerned with the measures that would be required to implement the policy and ameliorate its effects. If this were in fact the case, it would have been arguable that the Government's approach failed to conform to another of the requirements of art 4 of the Covenant.

\section{Reforms incompatible with the nature of the right?}

In addition, had there been a justiciable right to adequate housing in New Zealand, a real issue would have arisen about whether the reforms were incompatible with the right of Mrs Lawson and others to such housing.

The existence of such a right would not have meant that the rights of certain state house tenants would have always trumped the rights of others in need of housing (that is, that every tenant would have had an ongoing and inalienable right to the same standard of housing that they had prior to the reforms, no matter resource limitations or the needs of others); or that housing policy could never be changed. However, if the rights of some state tenants had to be restricted to achieve greater overall equity (such as requiring some tenants to move to smaller accommodation so that other people requiring larger state houses could be accommodated), such restrictions could not have been implemented in a way that effectively destroyed those tenants' rights.

In the context of the reforms, this would have meant that the Government (or HNZ) would have had to ensure that, before state tenants were required to move from accommodation which was adequate, and before tenants were required to pay market rates for such accommodation, there was in fact adequate, alternative housing (even if not of the same standard) on offer from HNZ or from other landlords. In other words, a policy which arguably improved the position of at least some members of one disadvantaged group (private tenants), but also resulted in people who formerly had access to adequate housing no longer having such access (for example, falling into the category of serious housing need because they had to move to substandard housing or had to expend a large proportion or the majority of their income on accommodation), would be unlikely to be compatible with the right to adequate housing.

Because Lawson v Housing New Zealand was not argued on this basis, it cannot be stated definitively that the Government knew that an effect of the reforms would be to push some tenants into inadequate housing, or whether that in fact happened. However, various facts in the judgment indicate that the Government was aware that this could occur, or at least did not have a solid factual basis for believing that it would not; and that some state tenants lost their former housing without any guarantee of an adequate replacement. 
New Zealand's initial report under the ICESCR, drafted before the reforms were implemented, recorded that: "The main problems [in relation to housing] are the high cost in the private sector of houses and finances, or of rents, relative to income". ${ }^{130}$ The judgment of Williams $\mathrm{J}$ also recorded this understanding. ${ }^{131}$ In addition, policy advice to Government recognised that it was essential to the reforms' success that there was an adequate supply of low-cost housing. ${ }^{132}$ Despite this, there is nothing in the judgment to indicate that the Government determined prior to the reforms' implementation that there was such supply. Indeed, as the reforms proceeded, it was noted in 1992 that there would be problems for tenants whose relocation options were constrained by a shortage of one-bedroom units. ${ }^{133}$ In 1994, one of the staggered rent increases was deferred due to a continuing shortage of smaller units. ${ }^{134}$

Further, in 1993 the Chair of the HNZ Board wrote to the Prime Minister, advising him that a rent increase planned for November 1993 would particularly impact on approximately 9,000 retired persons, mainly women, who would generally not be able to find alternative accommodation. These people had in the past been the best tenants. The increase would result in their paying more than 40 per cent, and in some cases more than 50 per cent, of their income on accommodation. The Chair advised the Prime Minister that this would cause "considerable individual distress". ${ }^{135}$ The Government, however, decided to proceed with the rent increase apparently without implementing any of the remedial strategies the Chair suggested, on the basis of advice that "the figures might have been overstated". 136

Therefore, the Government not only knew that the availability of adequate housing in the market was limited, but also knew that its reforms would force many tenants out of their current properties (indeed that was its intention) and simultaneously increase demand for smaller properties which were already oversubscribed. Despite this, the Government appears to have simply assumed that adequate housing would somehow be provided by a combination of market forces, HNZ, private landlords and the accommodation supplement. This assumption was apparently incorrect. Indeed, evidence before the Court (albeit contested) was that during the reforms the number of households

130 Initial reports submitted by States parties under articles 16 and 17 of the Covenant: New Zealand, above $\mathrm{n}$ 65 , at [415].

131 See Lawson, unreported judgment, above n 100, at 5.

132 Ibid, at 7.

133 Ibid, at 19.

134 Ibid, at 21.

135 Ibid, at 35 and 36 .

136 Ibid, at 36. 
in serious housing need rose significantly. These households included state tenants who could not afford to pay their rent and tenants in private accommodation. ${ }^{137}$

Apparently, one of these households was or was going to be the Lawsons'. As already stated above, there was no finding in the judgment against Mrs Lawson's allegation that the reforms had resulted in her having inadequate housing (in the sense that the rental increases had made her current housing unaffordable despite her and her husband taking measures such as doing without heating, that as a result they were subject to an application by HNZ to evict them, and that alternative accommodation in the same area was only available at a higher cost).

\section{Summary}

(a) Market rents: an apparently unjustifiable retrogressive measure

The facts recorded in the judgment of Williams $\mathrm{J}$ provide clear indications that the move to market rents constituted an unjustifiable retrogressive measure, incompatible with the right to adequate housing of numerous tenants. It appears that the reforms may well have resulted in many tenants being moved from a situation in which they could enjoy the right to a situation in which the right was effectively negated (and accordingly breached).

Mrs Lawson and her husband were some of the state tenants forced to move as a result of the implementation of market rents. Unfortunately, there is no indication in Williams J's judgment of what happened to the Lawsons following the termination of their tenancy for non-payment of rent, no doubt because, as Williams $\mathrm{J}$ found, any hardship which Mrs Lawson would experience as a result of the reforms was legally irrelevant. ${ }^{138}$ However, if the move to market rents meant that Mrs Lawson and her husband had to move out of their state house into substandard accommodation, then there would have been a clear argument that the Lawsons' right to adequate housing had been violated. From the information available from the judgment, that this could have occurred was clearly possible (unless Mrs Lawson and her ill husband, in their mid-70s and early 80s respectively at the time of the hearing, were able to find adequate housing outside the area in which they had lived for 49 years, or in another city).

(b) A role for the courts, and determining the scope of the right

Generally speaking, Williams $\mathrm{J}$ was correct in stating that a court should be reluctant to intervene in areas with high policy content. However, where there is evidence of considerable prejudice to people and indications that their rights (whether at international or domestic law) are

137 Ibid, at 40-41. I note that it is not clear from the judgment how many of the latter were already in private accommodation and how many were in private accommodation as a result of being unable to pay rent for a state house.

138 See Lawson $v$ HNZ, above $\mathrm{n}$ 4, at 488, where Williams $\mathrm{J}$ found that any hardship Mrs Lawson experienced was "insusceptible to judicial review". 
being breached by a certain policy, a substantive judicial review of the justifications for and proportionality of that prejudice, and of the measures taken to ameliorate it, should be available.

Such a review will not necessarily lead to a finding that a particular measure is impermissible, and indeed a finding in favour of the measure will strengthen its legitimacy. In the case of the housing reforms, given their severe consequences for many state tenants, the ability to invoke a rights-based, substantive judicial review would have been entirely appropriate (whatever the outcome of such a review). It would also have been consistent with New Zealand's international obligation to protect the right to adequate housing.

Further, a jurisdiction of this nature would not have required the Court to decide on the best way for the New Zealand Government to provide housing assistance. Rather, it would have simply permitted the Court to analyse the Government's reforms to ensure that they did not breach the right to adequate housing, affording the Government an appropriate margin of discretion.

Of course, before a court could make such an assessment it would have to determine the scope of the right to adequate housing. This would be a function the court would be well-equipped to carry out. In making its determination, the court would be assisted by the parliamentary materials on the right (given that if a court had jurisdiction to make such a determination, that would be because the legislature had decided to make the right justiciable as a matter of domestic law), including relevant select committee reports, parliamentary debates, and other materials which would shed light on why Parliament had adopted a particular formulation of the right. The court could also be informed by expert evidence, the CESCR's General Comment on the right, ${ }^{139}$ other international definitions and associated jurisprudence and academic commentary: in other words, the same interpretative aids that courts already use in statutory interpretation, including but not limited to the interpretation of the rights affirmed in the NZBORA. ${ }^{140}$

(c) Impact on policy

Finally, if such a right had been expressly recognised in domestic law before the reforms were implemented, the Government would have been much more likely to take that right and its associated obligations expressly into account in policy design. Consequently, it would have been much more likely that the right would have influenced that policy. It is difficult to see how such an influence could be negative. While Williams $\mathrm{J}$ was correct to a point in considering that policy cannot be designed to meet individual circumstances, policy can and should be designed to be consistent with fundamental human rights, including ensuring that those rights are not breached as a result of its implementation.

139 CESCR General Comment No 4 E/1992/23 (1991).

140 See also in this regard Opie, above n 1, at 214-221. 


\section{Move to income-related rents regime}

It is noteworthy that in 2000, the Labour Government (which in 1999 replaced the National Government responsible for the reforms) moved to an "income related rents" regime for tenants of the successor to HNZ, the Housing New Zealand Corporation. Under the new regime "Corporation tenants pay no more than $25 \%$ of their income in rent, although minimum rents do apply". ${ }^{141}$

The Lawsons' rent prior to the rent reforms was $\$ 75$ a week, which was 25 per cent of their income. ${ }^{142}$ It is not clear whether they would have benefitted from the move back to income-related rents, some four years after their tenancy was ended because of their inability to pay the market rate.

\section{B Free-Standing, Justiciable ESCR: Awareness Amongst the Population and a Check on Power}

As set out above, from 1984 through until the late 1990s successive New Zealand Governments implemented a series of retrogressive measures with little or no mandate and apparently in some cases on the basis of scant evidence or analysis. These measures substantially affected the extent to which many people enjoyed ESCR in New Zealand and could have constituted violations of ESCR.

At the same time, the New Zealand public appeared to be largely unaware that they had such rights as a matter of international law. As a matter of domestic law, and consistent with the intention of the Parliament which enacted the NZBORA, ESCR were not directly enforceable in New Zealand courts. Further, contrary to the Government's position (referred to in Part III above), ESCR were not adequately protected by other means. Lawson $v$ Housing New Zealand provides a useful example of the significant limitations of judicial review where ESCR are concerned, and the difficulties created by the lack of an express jurisdiction for New Zealand courts to inquire into whether Government policy or legislation breaches ESCR.

According to the White Paper, the purposes of the Bill of Rights it proposed included guaranteeing CPR, restraining the abuse of power by the State, acting as a source of inspiration, ensuring that individuals who suffered violations of their rights would receive remedies, and providing "a set of minimum standards to which public decision making must conform." 143 Another

141 See the Third periodic report submitted by States parties under articles 16 and 17 of the Covenant: New Zealand, above n 60, at [406], which also states:

Tenants with incomes above the New Zealand Superannuation low-income threshold will pay progressively more than 25 percent of their income, until the market rate is reached. Around 90 percent of Corporation tenants pay an income-related rent.

142 Lawson, unreported judgment, above n 100, at 37.

143 Palmer "White Paper", above n 28, at 5. 
of its purposes was to educate New Zealanders about their rights. As the White Paper forcefully argued: ${ }^{144}$

[The Bill of Rights] will be an important means of educating people about the significance of their fundamental rights and freedoms in New Zealand society. Citizens will have a readily accessible set of principles by which to measure the performance of the Government and to exert an influence on policymaking. An awareness of basic human rights and fundamental freedoms amongst citizens and a desire to uphold them is as powerful a weapon as any against any Government which seeks to infringe them. In this way too, the Bill of Rights will be a powerful influence on the Government, its officials and agencies.

All of these reasons for providing CPR with a special status in the NZBORA applied with equal force to ESCR (and continue to apply today). However, the omission of ESCR from the NZBORA meant that the Act was precluded from the outset from fulfilling any of the objectives listed above in relation to ESCR. As a result, ESCR were left exposed.

Recognition of ESCR in the NZBORA could have had a number of important effects in relation to the reforms which occurred after its enactment in 1990. For example, as argued above in the context of Lawson $v$ Housing New Zealand, Government would have been much more likely to take ESCR expressly into account in making policy and law, and affected individuals or representative organisations would have been able to invoke a substantive judicial review of Government policy that affected ESCR. In addition, there would have been an express statutory directive to interpret legislation consistently with ESCR where possible.

The inclusion of ESCR in the NZBORA could have slowed the pace of the reforms; ${ }^{145}$ tempered their severity by contributing to a more cautious approach from the outset; encouraged more robust and evidence-based policy; ${ }^{146}$ promoted ESCR through expressly requiring ESCR-

144 At [9.1].

145 Had justiciable ESCR had such an effect, it could have been beneficial. According to Hazledine and Quiggan, above n 71, at 152:

... Australia's superior performance supports the view that the speed with which the New Zealand reforms were implemented contributed to poor observed outcomes. Excessive speed was problematic in itself, since it increased adjustment costs, and was frequently associated with poor implementation and a preference for dogmatism over practicality.

146 In this regard, see Etienne Mureinik "Beyond a Charter of Luxuries: Economic Rights in the Constitution" (1992) 8 SAJHR 464 at 472-473, who argues as follows:

[I]f the government is confident of the economic case [for any particular programme or policy], let it make it in court, where it can be exposed to scrutiny. If the government could adduce economic [and any other relevant] evidence and argument to make a plausible case, the court would have to uphold the programme. A central deficiency of the present order is that the economic case for a government programme, if it is made at all, is made at the level of slogan and newspaper headline, and, occasionally, at the not much less superficial level 
consistent interpretations of legislation where such interpretations were open; and led to the identification of conduct that was inconsistent with ESCR (thereby protecting and upholding those rights). Justiciable ESCR could have provided an important and democratic check on the State's power, particularly given the context of democratic failure in which the reforms occurred.

As the NZBORA is not supreme law, the inclusion of ESCR in it would not have prevented any Government from implementing reforms it deemed necessary. However, to the extent that such reforms were inconsistent with ESCR and were not prescribed by law, a court could have made a declaration to that effect. It would then have been up to the Government to modify its policies so as to make them ESCR-consistent, or to decide to override ESCR by enacting expressly inconsistent legislation (as the NZBORA permits). Courts would also have had the jurisdiction to indicate such legislative inconsistency.

At each stage of the reforms, the Government would have had to consider directly the implications of any particular policy or law for the fundamental interests that ESCR represent, and the population would have had a set of internationally and domestically validated human rights standards against which to evaluate the Government's actions. Importantly, substantive judicial review could also have allowed for findings that measures which now appear, perhaps with the benefit of hindsight and on the basis of incomplete information, highly problematic with respect to ESCR were not in fact ESCR-inconsistent.

\section{CRITIQUE OF THE REASONS FOR OMITTING ESCR FROM THE NZBORA}

For the reasons set out above, there is a need for ESCR to have additional protection in New Zealand domestic law. The most obvious way of achieving this (at least as an initial measure) would be to incorporate these rights into the NZBORA and thereby provide them with the same status as CPR: that is, free-standing rights which directly influence statutory interpretation, law and policymaking, that override inconsistent subordinate legislation and inconsistent policy, but give way to ordinary inconsistent legislation (and acts carried out or policy made pursuant to such legislation).

permitted by the constraints of parliamentary procedure. Nothing requires the case to submit to searching scrutiny. Even if constitutional review of the kind suggested here proved to have no substantive bite at all - even, that is, if it resulted in the annulment of not a single programme - the procedural benefits would be immense. The knowledge that any government programme could be summoned into court for searching scrutiny would force its authors closely to articulate their reasons for dismissing the objections and the alternatives to the programme, and precisely to articulate the reasons that link evidence to decision, premises to conclusion. The need to articulate those reasons during decisionmaking would expose weaknesses in the programme that might force reconsideration long before the need arose for judicial challenge.

See also Opie, above n 1, at 214-231. 
Accordingly, it is important to analyse the reasons given in the White Paper and elsewhere for excluding ESCR from the NZBORA, and consider whether those reasons provide sufficient justification for not providing ESCR with the same status as CPR. In my view, they do not.

\section{A Policy, Not Right?}

Contrary to the argument in the White Paper, the inclusion of ESCR in the NZBORA would not involve the imposition or the freezing into place of a "temporarily popular view of policy." 147

\section{ESCR are fundamental rights}

The preambles to the ICESCR and the ICCPR record the acknowledgement of States parties (including New Zealand) that both ESCR and CPR derive from the inherent dignity of the human person. Further, ESCR and CPR are indivisible and interdependent: as the preambles to the Covenants state, "the ideal of free human beings enjoying freedom from fear and want can only be achieved if conditions are created whereby" all may enjoy their ESCR and CPR.

Through its ratification of the Covenant, New Zealand has affirmed its values and accepted as binding upon it the obligations the Covenant imposes. So has the majority of the international community: 160 States including New Zealand are currently parties to the Covenant. The considerable degree of adherence to the Covenant demonstrates the wide and ongoing acceptance of its values and objectives.

Accordingly, ESCR cannot be equated with "temporarily popular" policy. To the contrary, ESCR are fundamental human rights, of equal importance to CPR.

\section{Freezing in place a particular policy framework?}

As the CESCR has stated: ${ }^{148}$

$\ldots$ in terms of political and economic systems the Covenant is neutral and its principles cannot accurately be described as being predicated exclusively upon the need for, or the desirability of a socialist or a capitalist system, or a mixed, centrally planned, or laisser-faire economy, or upon any other particular approach.

Rather, "the rights recognized in the Covenant are susceptible of realization within the context of a wide variety of economic and political systems". ${ }^{149}$

Therefore, the ICESCR does not make the use of a certain economic system or set of policies mandatory. Neither does it require States parties to adopt and maintain one set of policies

\footnotetext{
147 Palmer "White Paper", above n 28, at [3.14].

148 CESCR General Comment No 3, above n 14, at [8].
}

149 Ibid, at [8]. 
indefinitely. Indeed, such a course of action would be likely to frustrate ESCR realisation rather than promote it.

\section{Birthright}

Far from being passing considerations, the majority of the ESCR recognised in the ICESCR are what many New Zealanders would consider as their birthright and as part of the country's heritage.

For example, the guarantee of access to decent health care and education regardless of one's ability to pay can be seen as a fundamental commitment in New Zealand. The same applies to adequate social security for those who cannot work (for reasons such as illness, disability, old age, or unemployment), and to access to employment for those who can work. At a more general level, one of the themes running through ESCR is equality, and this is a core New Zealand value. The White Paper itself referred to "the strong and long-standing emphasis on equality in New Zealand social and political thinking" and described it as a "central and paramount value [which] can be traced far back in our modern history and indeed can be discerned in the Treaty of Waitangi itself." 150

These commitments (for example, to suitable education, to adequate health care, and to equality) can be seen as constitutive, in that they form part of New Zealand's basic values. ${ }^{151}$ Given that, and as the Justice and Law Reform Select Committee recognised in 1988, ${ }^{152}$ they merit a place in New Zealand's constitutional law.

It is also important to recall that the argument made in the White Paper against ESCR was in the context of the proposal to enact the Bill of Rights as supreme law. It has even less force in the

150 Palmer "White Paper", above n 28, at [10.75]. See also CESCR General Comment No 20 E/C.12/GC/20 (2009) at [3], which states:

The principles of non-discrimination and equality are recognized throughout the Covenant. The preamble stresses the 'equal and inalienable rights of all' and the Covenant expressly recognizes the rights of 'everyone' to the various Covenant rights such as, inter alia, the right to work, just and favourable conditions of work, trade union freedoms, social security, an adequate standard of living, health and education and participation in cultural life.

151 I have borrowed the idea of a "constitutive commitment" from Cass R Sunstein The Second Bill of Rights (Basic Books, New York, 2004) at 62. Sunstein uses this concept to describe rights which are not expressly set out in the Constitution of the United States, but nonetheless "have a special place in the sense that they are widely accepted and cannot be eliminated without a fundamental change in social understanding." These rights may be considered as "constitutive commitments" because they "help create, or constitute, a society's basic values", are "expected to have a degree of stability over time", and "[a] violation of them would amount to a kind of breach - a violation of a trust."

152 "Justice and Law Reform Committee Final Report", above n 38, at 4. 
context of the NZBORA as enacted, which does not override inconsistent legislation and can be amended by a simple majority. ${ }^{153}$

\section{B Positive ESCR vs Negative CPR, Judicial Capacity and Enforceability}

As set out in Part III above, another argument made in the White Paper against ESCR was that these rights create positive obligations on the State to provide for certain entitlements. Therefore, they are costly. CPR, on the other hand, impose principally negative duties, in that they simply require the State to refrain from certain acts. Accordingly, CPR are cost-free or very low cost. ${ }^{154}$

As a result, the enforcement of CPR allegedly creates fewer issues for courts than the enforcement of ESCR. Rather than having to require the Government to expend taxpayer funds and potentially breach separation of powers principles (as ESCR allegedly require for their enforcement), CPR merely require the imposition of negative orders (for example, do not torture). As set out in Part III of this article, Geoffrey Palmer appeared to consider that if ESCR were justiciable rights in New Zealand, the judiciary would encroach on areas reserved for the executive and the legislature, and would be required to adjudicate upon social and economic issues in which they had insufficient expertise.

In my view, these arguments are flawed.

\section{All rights have positive elements}

Contrary to the position advanced in the White Paper, CPR as well as ESCR have positive elements and rely upon publicly funded institutions to create the conditions in which they can be realised. The protection of CPR requires the taking of positive measures, including the enactment of legislation, monitoring, and enforcement. ${ }^{155}$

For example, the electoral rights in s 12 of the NZBORA cannot be exercised in the absence of adequately supervised elections paid for with public funds. The minimum standards of criminal procedure set out in s 25 of the NZBORA, including the right to a fair and public hearing by an independent and impartial court, require the establishment and maintenance of a costly court system. The s 24(f) right of a person charged with an offence to receive legal assistance without cost "if the interests of justice so require", and if the person does not have access to sufficient funding, cannot

153 See also in this regard Opie, above n 1, at 230-231.

154 See also in this regard and for example EW Vierdag "The Legal Nature of the Rights Granted by the International Covenant on Economic, Social and Cultural Rights" (1978) 9 NYIL 69 at 81-82.

155 See in this regard Stephen Holmes and Cass R Sunstein The Cost of Rights (WW Norton \& Company, New York, 1999) at 44. 
be realised in the absence of a legal aid system. ${ }^{156}$ The right of prisoners to be treated humanely and with respect for their dignity, as set out in s 23(5) of the NZBORA, requires significant expenditure to ensure that prison guards are adequately trained and minimum standards (for example, of cleanliness, medical care, and food) are maintained in prison. ${ }^{157}$ The protection of rights such as the right to property (not expressly guaranteed in the NZBORA but otherwise provided for in a range of other legislation) requires the ongoing funding of the courts, the police force and the prisons. ${ }^{158}$

In New Zealand, as in many other jurisdictions, courts are empowered to award damages against the State for CPR breaches, and those damages have to be paid from public revenue. Further, to ensure the rights of prisoners "[c]ourts have ordered that prisons be built to relieve overcrowding"; 159 and judgments that States have unreasonably delayed bringing an accused to trial have placed "incentives on the state to increase the capacity of the judicial system by building new

156 See also Malcolm Langford "The Justiciability of Social Rights: From Practice to Theory" in Malcolm Langford (ed) Social Rights Jurisprudence: Emerging Trends in International and Comparative Law (Cambridge University Press, New York, 2008) 3 at 30.

157 In "Reclaiming Economic, Social and Cultural Rights" (1993) 1 Waikato L Rev 141 at 152-153, Paul Hunt provides a table setting out the New Zealand Government's expenditure on various CPR. Although Hunt's table is not exhaustive and dates from 1993, it nonetheless illustrates that "the realisation of civil and political rights is neither a cost-free exercise nor one requiring only modest state expenditure." Hunt estimates a total expenditure of \$213.32 million, including \$59.51 million on "Administrative Services to Courts and Tribunals", \$49.11 million on "Administration of Court Sentences of Imprisonment", and \$6.60 million on legal aid. More recently, a Capital Letter editorial (Penny Pepperell "Criminal Justice: Has the Tide Turned?" The Capital Letter (Auckland, 7 February 2012) at 1) recorded that between 2000 and 2011 "spending on the justice system increased from $\$ 1.7$ to nearly $\$ 4.0$ billion."

158 See further Holmes and Sunstein, above n 155, at 60-64 discussing the costs of property rights in the United States. Amongst other figures, the authors cite the following: "In 1992, direct expenditures in the United States for police protection and criminal corrections ran to some $\$ 73$ billion". Note also a forecast of the current Minister of Finance, Bill English, that the Department of Corrections would become the largest government department in New Zealand by 2012 or 2013 in terms of the number of directly employed employees, outstripping the Ministry of Social Development and the Inland Revenue Department. This was because Corrections was going to have to employ more staff to cope with an expected increase in the prison muster. In addition, stating that the Ministry of Justice, the Police and Corrections would need "to find" $\$ 400$ million from their existing budgets in the next three years to cope with the projected increase in the muster, the Minister warned that costs would continue to rise if more punitive justice measures were implemented. The Minister was quoted as stating:

Every time you ask for harsher penalties, that shortfall gets bigger. You are part of the driver of the costs. Lock another person up that's another $\$ 90,000$ (a year) plus another $\$ 250,000$ capital (spending).

See Derek Cheng "Corrections to become monster department" The New Zealand Herald (online ed, Auckland, 2 July 2010).

159 Craig Scott and Patrick Macklem "Constitutional Ropes of Sand or Justiciable Guarantees? Social Rights in a New South African Constitution" (1992) 141 U Pa L Rev 1 at 61. 
courts and hiring extra judges and staff." 160 Decisions upholding the right to due process have "increased the costs of administrative tribunals enormously." 161

Accordingly, courts often require the State to direct resources to the fulfilment of rights which cannot then be applied to other purposes. Indeed, in most jurisdictions with justiciable CPR, including New Zealand, such expenditure is required even in the absence of specific judgments: the State must expend resources to realise guaranteed CPR to reduce the risk of costly proceedings being brought against it.

Finally, as Langford contends, while it may be argued that some ESCR require greater expenditure for their realisation than CPR, this is "a matter of degree rather than substance." 162 Indeed, the greater the amount of public funds involved, the greater the need for rigorous checks and balances, including a jurisdiction for the courts.

\section{Judicial capacity}

The argument that New Zealand judges do not have the capacity to adjudicate on ESCR is weak. First, as set out in Part III, they already adjudicate on aspects of these rights under legislation such as the HRA, the Employment Relations Act, the Holidays Act, and the Accident Compensation Act. Second, while the enactment of ESCR in New Zealand law as justiciable rights would require judges to develop greater knowledge about these rights, this task would not be beyond them. Judges are often required to deal with new areas of law; indeed, the NZBORA was novel when it was first enacted. Third, if a wider range of expertise were thought desirable for ESCR cases, the presiding court could be comprised of not only judges but also lay people with relevant expertise, ${ }^{163}$ as already occurs under the HRA ${ }^{164}$ and in litigation under the Commerce Act $1986 .{ }^{165}$ As in any case, expert witnesses could also be called to assist.

160 Ibid, at 48. See further Scott and Macklem's discussion of judgments of the European Court of Human Rights regarding the obligations of the State to ensure the timely administration of justice (both in civil and criminal settings) at 48 .

161 Ibid, at 50.

162 Langford, above n 156, at 30-31.

163 See also in this regard Smillie, above n 43, at 194.

164 Section 126 of the HRA states that in certain cases, matters brought to the High Court under the HRA must be heard by a High Court judge and two additional persons appointed from a panel selected by the Minister of Justice in accordance with s 101 of the HRA (as occurred in CPAG v AG, above $\mathrm{n} 63$ ). The members of the panel, who do not all have to be lawyers, are also eligible to serve on the HRRT. In selecting the panel, $s$ 101 requires the Minister to have regard to:

... the need for persons included on the Panel to have between them knowledge of, or experience in,-

(a) different aspects of matters likely to come before the Tribunal: 
The White Paper stated that, in enforcing the supreme law Bill it proposed, the courts: ${ }^{166}$

... would be exercising, in part in an enhanced way, their historic constitutional role of protecting the individual, especially the weak, the disadvantaged, the member of an unpopular minority, against the State.

The role of the courts under the NZBORA is less than what it would have been under a supreme law Bill, but it still conforms with this characterisation. Indeed, this role may be seen as one of the courts' core functions. If New Zealand courts were given jurisdiction over enforceable ESCR, this core function would be extended but not substantially modified. ${ }^{167}$

It was also argued in the White Paper that, under a Bill of Rights: 168

... [t]he courts will have a role. It will be a crucial one but it will not be an exclusive one. The Bill of Rights should be thought of as providing a floor. The life of the state can and should rise far above it.

There is no reason why ESCR and the role of the courts in relation to these rights could not have been or could not now be conceptualised in the same way.

Finally, it is likely that if ESCR were recognised as free-standing rights in New Zealand, the involvement of the courts in issues formerly designated as wholly political would increase. However, for the reasons set out above, a greater role for the New Zealand courts in relation to the protection of ESCR is desirable. ${ }^{169}$

(b) New Zealand law, or the law of another country, or international law, on human rights:

(c) public administration, or the law relating to public administration:

(d) current economic, employment, or social issues:

(e) cultural issues and the needs and aspirations (including life experiences) of different communities of interest and population groups in New Zealand society.

165 See the Commerce Act 1986, ss 77 and 78. Section 77 requires amongst other matters that a person appointed as a lay member under the Act be "qualified for appointment by virtue of that person's knowledge or experience in industry, commerce, economics, law, or accountancy."

166 Palmer "White Paper", above n 28, at [3.10].

167 For example, the courts would have an express jurisdiction to inquire into whether benefit cuts violated the rights of beneficiaries (a weak, disadvantaged and often unpopular group) to adequate food, clothing and housing and to social security more generally.

168 Palmer "White Paper", above n 28, at [4.5].

169 In this regard, note also the following comment by Lord Steyn in "Deference, a Tangled Story" [2005] PL 346 at 357 (cited in CPAG v AG, above n 63, at [142]):

Most legislation is passed to advance a policy. And frequently it involves in one way or another the allocation of resources. ... What I am saying is that there cannot be a legal principle requiring the court to desist from making a judgment on the issues in such cases.... 


\section{ESCR: unmanageable, unenforceable or incapable of judicial resolution?}

There is no evidence that ESCR suffer from such inherent defects. ESCR are recognised as justiciable rights in, for example, the Brazilian, South African and Finnish Constitutions, and the courts have decided a wide range of cases involving these rights. The judgments of these courts demonstrate that ESCR do not make a Bill of Rights or a constitution unmanageable. To the contrary, the constitutionalisation of ESCR in Brazil, South Africa and Finland has provided an important check on the powers of the legislature and executive, and a critical source of protection for people who have not otherwise been well served by democratic processes.

For example, the right to health recognised in the Brazilian Constitution has provided the foundation for a large number of court rulings requiring that indigent HIV sufferers be provided with free medication. The constitutional right to free preschool education has also been used to force State authorities to provide that education to children from low-income families. The South African Constitutional Court's judgment in Minister of Health and Others $v$ Treatment Action Campaign and Others (No 2), ${ }^{170}$ based on the constitutional right to access to health services, required the State to remove unreasonable restrictions on the availability in the public health sector of a drug used to prevent the transmission of HIV from mother to child. The Finnish courts and the Finnish Constitutional Law Committee have applied the social security rights guaranteed in the Finnish Constitution to prevent the State denying the minimum benefits necessary for a dignified life to groups who could not provide for themselves. ${ }^{171}$ Without the courts, the beneficiaries of these judgments (and in the case of Finland, of the Constitutional Law Committee's opinions) would have had no remedy.

There is in my view no justification for a court to adopt an a priori view in favour of economic conservatism. In common law adjudication it is an everyday occurrence for courts to consider, together with principled arguments, the balance sheet of policy advantages and disadvantages. It would be a matter of public disquiet if the courts did not do so. Of course, in striking the balance the courts may arrive at a result unacceptable to Parliament. In such cases Parliament can act with great speed to reverse the effect of a decision. ... But there is no need to create a legal principle requiring the courts to abstain from ruling on policy matters or allocation of resource issues.

170 Minister of Health and Others v Treatment Action Campaign and Others (No 2), above n 44.

171 For summaries of ESCR cases under the Brazilian, Finnish and South African Constitutions, see Opie, above n 1, chs 3 (at 96-103), 4 (at 133-136) and 5 (at 165-187). For a discussion of the role of the Finnish Constitutional Law Committee and its ESCR-related opinions, see Opie, at 126-128 and 136-138. 
It is also arguable that the inclusion of ESCR has increased the legitimacy and relevance of the Brazilian, South African and Finnish Constitutions. ${ }^{172}$ Indeed, most national constitutions now affirm ESCR. ${ }^{173}$

Further, if the New Zealand Parliament considered that the terms in which ESCR are expressed in the ICESCR are insufficiently precise or unsuited to the New Zealand context, there would be nothing preventing Parliament from enacting the rights in the NZBORA in different terms to those used in the ICESCR (provided that such rights were not inconsistent with those set out in the ICESCR). ${ }^{174}$ The Finnish, South African and Brazilian Constitutions are precedents for such an approach. For example, rather than guaranteeing a right to the "highest attainable standard of physical and mental health", as in art 12 of the ICESCR, the right referred to in s 19(3) of the Finnish Constitution is to "adequate social, health and medical services." Similarly, s 27(1) of the South African Constitution is limited to affirming the right to "access to health care services." In the

172 Ibid, at 115-118, 149-153 and 202-203. In relation to South Africa, note Nicholas Haysom "Constitutionalism, Majoritarian Democracy and Socio-Economic Rights" (1992) 8 SAJHR 451 at 454, who argues:

[F]or a constitution to have a meaningful place in the hearts and minds of the citizenry, it must address the pressing needs of ordinary people. It cannot be seen to institutionalise and guarantee only political/civil rights ... it must promise both bread and freedom. If it does not do so, it will find no lasting resonance amongst the true guardians of the constitution - which are not the courts but the citizens (emphasis in original).

173 See Zachary Elkins, Tom Ginsburg and James Melton The Endurance of National Constitutions (Cambridge University Press, New York, 2009) at 28. With reference to their database, which includes data on every national constitution written since 1789, the authors state:

As is well-known, the menu of 'required' rights has expanded dramatically since the days when the negative rights enshrined by the U.S founders seemed complete. Second and third generation rights, the positive rights, are now included in international covenants as well as most national constitutions (emphasis added).

Note however that the authors do not provide any information on the extent to which such rights are justiciable in the national constitutions to which they refer (as opposed to being, for example, unenforceable directive principles). See further Opie, above n 1, at 247-249.

174 For more detail, see Opie, above n 1, chs 3, 4, and 5. Note also in this regard that neither the Bill of Rights as originally proposed in the White Paper nor the NZBORA as ultimately enacted followed the drafting used in the ICCPR. As stated in Palmer "White Paper", above n 28, at [10.10]-[10.12], while the Bill was said to be consistent with the ICCPR, it was also noted that:

... the text of the Bill departs considerably from that of the [ICCPR] both in phraseology and arrangement. In some respects the language of the [ICCPR] appears too detailed or unsuited to a New Zealand statute. It was fashioned to meet the varying circumstances of all countries that participated in drawing it up. A number of its provisions have little relevance to the situation in New Zealand. Consequently, many of the Articles of the [ICCPR] have no corresponding provision in the Bill of Rights. 
Brazilian Constitution, and in contrast to the ICESCR, none of the affirmed "social rights" are subject to progressive realisation: all are required to be immediately guaranteed.

Finally, if Parliament considered that additional guidance should be given to the courts about the content of ESCR, elements of these rights could be particularised in the NZBORA. This was the course Parliament took in relation to some of the CPR affirmed in the NZBORA. For example, rather than simply affirming the right to a fair trial and nothing more, s 25 of the NZBORA sets out "minimum standards of criminal procedure". These minimum standards include the right to a fair and public hearing by an independent and impartial court; the right to be tried without undue delay; and the right to be presumed innocent until proven guilty according to law. ${ }^{175}$ There is no reason why such minimum standards could not also be devised in respect of ESCR (for example, for the rights to adequate housing, social security or education).

\section{Unrealistic Expectations?}

As set out above, Palmer considered that "to state as fundamental rights matters which it was not within the power of government to deliver would cause expectations to rise, only to be dashed." 176 In New Zealand, however, the State should be in the position to guarantee most if not all of these rights. If it is not, then this would only add strength to the argument that the legal status of such rights should be enhanced by enacting them in the NZBORA, but perhaps subject in some cases (such as the right to adequate housing) to progressive realisation, as in the Covenant. ${ }^{177}$ This would assist in ensuring that the Government prioritises their realisation over less fundamental interests.

175 Section 25 of the NZBORA also affirms the following rights:

(d) The right not to be compelled to be a witness or to confess guilt:

(e) The right to be present at the trial and to present a defence:

(f) The right to examine the witnesses for the prosecution and to obtain the attendance and examination of witnesses for the defence under the same conditions as the prosecution:

(g) The right, if convicted of an offence in respect of which the penalty has been varied between the commission of the offence and sentencing, to the benefit of the lesser penalty:

(h) The right, if convicted of the offence, to appeal according to law to a higher court against the conviction or against the sentence or against both:

(i) The right, in the case of a child, to be dealt with in a manner that takes account of the child's age.

176 Palmer New Zealand's Constitution in Crisis, above n 41, at 57.

177 See Opie, above n 1, at 258-275, for a version of the NZBORA amended to include a range of ESCR and a discussion of the suggested amendments. 


\section{Mandatory Relevant Considerations and the Presumption of Consistency: Sufficient Protection for ESCR through the Common Law?}

As set out in Part III above, the New Zealand Government's position has been that it is unnecessary to include ESCR in the NZBORA as they are adequately protected by other means, including through the common law. ${ }^{178}$ As briefly discussed in Part III, two common law mechanisms which are relevant in this regard are the administrative law requirement that decisionmakers exercising statutory powers of decision take into account all mandatory relevant considerations; and the common law presumption of statutory interpretation that "so far as its wording allows legislation should be read in a way that is consistent with New Zealand's international obligations". ${ }^{179}$

For the reasons set out below, however, neither mechanism provides sufficient protection for ESCR.

\section{Mandatory relevant considerations}

A decision-maker exercising a statutory power of decision which affects ESCR may well be required to take into account New Zealand's obligations under the ICESCR (provided this is not expressly or impliedly excluded by the relevant statute). ${ }^{180}$ As set out above, one of Mrs Lawson's pleadings in Lawson $v$ Housing New Zealand was advanced along these lines. ${ }^{181}$

178 See Initial reports submitted by States parties under articles 16 and 17 of the Covenant: New Zealand and Second periodic reports by States parties under articles 16 and 17 of the Covenant: New Zealand, above $n$ 65.

179 New Zealand Air Line Pilots' Association Inc v Attorney- General [1997] 2 NZLR 269 (CA) at 289. Note also Ye v Minister of Immigration [2009] NZSC 76, [2010] 1 NZLR 104 at [24] and [32], in which Tipping $\mathrm{J}$ characterised the presumption as follows:

This construction [of s 47(3) of the Immigration Act 1987] gives effect to the principle that Parliament has legislated consistently with international obligations unless the contrary is clearly shown or unless the language used does not allow that outcome (emphasis added).

For a detailed analysis of the presumption see Claudia Geiringer "Tavita and All That: Confronting the Confusion Surrounding Unincorporated Treaties and Administrative Law" (2004) 21 NZULR 66 at 75.

180 See, for example, Tavita $v$ Minister of Immigration [1994] 2 NZLR 257 (CA) at 266, cited in Lawson v $H N Z$, above $\mathrm{n} 4$, at 497. See also Geiringer, above $\mathrm{n} 179$, at 73-74.

181 Note however that Mrs Lawson's pleading was that the Ministers of Housing and Finance failed to have proper regard to New Zealand's obligations under the ICESCR (that is, an allegation not of a complete failure to have regard to these obligations, but an allegation that the regard had was insufficient). For the reasons set out in Parts IV and V above, Williams J did not uphold this allegation. Note also (and in any case) Geiringer's reference to "the blindness of the mandatory relevant considerations model to questions of weight or justification": Geiringer, above n 179, at 89-90. 
The principal weakness of such a requirement, however, is that even where it applies, the decision-maker only has to take into account the relevant obligations. Having done that, he or she may choose to make a decision which is inconsistent with the ICESCR. ${ }^{182}$ While having to consider such obligations may affect the decision in question (including swinging it in favour of an ESCRconsistent outcome), it also may not.

A further (and counter-intuitive) difficulty with the model is that the courts may find that a decision-maker has met the requirement to have regard to relevant ICESCR obligations even where he or she has not expressly considered those obligations. As set out in Part IV above, in Lawson v Housing New Zealand Williams J found that the Ministers had not expressly taken the ICESCR into account, but also found that: ${ }^{183}$

... [the] law does not appear to require Ministers to give specific consideration to such instruments [the ICESCR and the Universal Declaration on Human Rights] so long as they inform the decision-making process.

Williams J considered that that had occurred. Therefore, the Ministers had in effect, even if not in fact, had regard to the relevant obligations. ${ }^{184}$

Accordingly, the mandatory relevant considerations model provides, at best, very limited protection for ESCR.

\section{Presumption of consistency}

As far as I am aware, the presumption of consistency has not been raised in any case before the New Zealand courts in which the ICESCR has been cited. It is, however, potentially a more potent instrument for protecting ESCR than the mandatory relevant considerations model. On the basis of

182 Geiringer, above n 179, at 83-84.

183 Lawson $v$ HNZ, above $\mathrm{n}$, at 498.

184 See also Ankers v Attorney-General [1995] 2 NZLR 595 (HC) at 601-602, in which Thorp J adopted a very similar approach to Williams J. In this case, the applicant alleged amongst other matters that in making directions relating to the granting of special benefits, the Minister of Social Welfare failed to take into account New Zealand's obligations under arts 2(1), 9, 10 and 11 of the ICESCR. Thorp J found that officials of the Department of Social Welfare had not specifically referred the Minister to the Covenant obligations when he made the directions, but that it was "totally improbable" that "the Minister would be unaware of the tension between the type of restructuring of income support for the less advantaged which the government was undertaking and its international obligations". Thorp J also found that the Minister was not referred to the obligations because the officials considered that the directions would not conflict with them. On the basis of those findings, and also citing authority that the collective knowledge of departmental officials was to be treated as the knowledge of the relevant minister, Thorp J dismissed the allegation that the Minister had failed to take into account the relevant ICESCR obligations (although ultimately found in the applicant's favour on other grounds). 
this presumption, it could be argued that where such an interpretation is open, legislation affecting ESCR should be read consistently with New Zealand's obligations under the ICESCR.

For example, in Lawson $v$ Housing New Zealand, it could have been argued that the scope of HNZ's authority or discretion to act (as principally defined by s 4 of the Housing Restructuring Act, which required HNZ to operate as a successful business that would assist in meeting the Crown's social objectives) had to be interpreted consistently with New Zealand's obligations under the ICESCR. On such an interpretation, the HR Act would have impliedly required HNZ not to take any action or omit to do any act which would result in New Zealand violating its obligations under the ICESCR; or put another way, that HNZ's discretion to act was limited to actions consistent with New Zealand's obligations under the ICESCR, including the obligation to respect the right to adequate housing.

If that interpretation of HNZ's powers and obligations had been accepted, together with an argument along the lines set out above that HNZ's decision to charge market rents was incompatible with the right to housing under the ICESCR, it would have been strongly arguable that the decision was unlawful. ${ }^{185}$ Accordingly, if the presumption of consistency had been raised in Lawson $v$ Housing New Zealand, and if Williams J had been persuaded to interpret the HR Act in this way, perhaps it could have affected the outcome of the case. ${ }^{186}$

However, while the presumption could perhaps have assisted in Lawson $v$ Housing New Zealand, and may assist in future ESCR litigation, it is not enough.

Because ESCR are fundamental rights, they should be expressly affirmed in the NZBORA. A common law presumption of statutory interpretation in favour of ESCR is at best (and if in fact applied by the courts) an indirect, limited and potentially convoluted way of giving some effect to these rights in domestic law. As has already been recognised in the case of CPR, such a presumption is no substitute for the enactment of ESCR in the NZBORA as freestanding, enforceable rights

185 This argument assumes that the presumption of consistency could apply in interpreting HNZ's obligations and powers under the HR Act, even though HNZ was a company incorporated under the Companies Act 1955 rather than, for example, a public sector agency. Generally speaking, a court would be less likely to hold that the presumption applied to legislation concerning the rights and obligations of private rather than public entities. However, in Lawson $v$ HNZ, above n 4, at 493, and while not expressing a concluded view, Williams $\mathrm{J}$ considered that the NZBORA appeared to apply to HNZ's implementation of the market rent policy (in terms of s 3(b) of the NZBORA, being an act by a body in the performance of any public function, power, or duty conferred on that body by or pursuant to law). If the NZBORA applied to HNZ, there would seem to be no reason why the presumption of consistency could not also apply to HNZ's empowering legislation.

186 Similarly, it could perhaps also have been argued that given New Zealand's obligations under the ICESCR in relation to housing, the injunction to HNZ in the HR Act to act as a successful business had to give way to the requirement to assist in meeting the Crown's social objectives in relation to housing, where those two conflicted (or more generally where acting as a successful business would conflict with the right to adequate housing as defined in the ICESCR). 
(included in the express statutory direction in s 6 of the NZBORA to the courts to interpret legislation consistently with the affirmed rights where possible, and coming within the AttorneyGeneral's reporting obligations under s 7).

Also, given Parliament's express intention not to include ESCR in the NZBORA when it was enacted, the courts could be exposed to allegations of attempting to import these rights through the backdoor if, for example, they used the presumption of consistency to require that statutory powers be exercised in a manner consistent with ESCR. ${ }^{187}$ This, combined with the courts' traditional reluctance to adjudicate in areas of social and economic policy, ${ }^{188}$ could mean that courts would be inclined to take a hands-off approach in deciding whether the ICESCR obligations had been complied with in a particular case (for example, by giving the relevant decision-maker a very broad margin of discretion); to interpret narrowly the scope of those obligations; or to decide that there was no room in the particular statutory scheme for the presumption to apply. On the other hand, affirming ESCR expressly in the NZBORA would ensure that there could be no doubt about the role the courts should take in relation to ESCR: the same role as they now have in relation to the affirmed CPR. ${ }^{189}$

Finally, the presumption does nothing to address the unequal status that ESCR have in relation to CPR in New Zealand domestic law. Unless ESCR are recognised in the NZBORA, they are likely to continue to have little impact on New Zealand law and to remain little known by the New Zealand public. Conversely, an affirmation of ESCR in the NZBORA would considerably increase their visibility and relevance, for the New Zealand public in general, and also for officials, decisionmakers, legislators, lawyers, and judges. It would, in Palmer's words, provide another "set of navigation lights for the whole process of government to observe". ${ }^{190}$ It would also allow the New

187 See in this regard Geiringer, above n 179, at 77.

188 See in this regard Lawson $v$ HNZ, above n 4, at 487-488 and 494-496. See also Geiringer and Palmer, above $\mathrm{n} 57$, at 37 , who state that:

New Zealand courts have expressed a general reluctance to bring their judicial review powers to bear in the area of socioeconomic entitlement because of the 'political' nature of social policy questions.

189 In this regard, note Miller J's judgment in Attorney-General v Human Rights Review Tribunal and Child Poverty Action Group Incorporated (2006) 18 PRNZ 295 (HC) (dismissing the Attorney-General's claim that CPAG lacked standing to bring the proceedings before the HRRT referred to in $n 63$ above). At [64] [65], Miller J stated:

[T] he proposition that the Courts have no business adjudicating upon claims that have serious resource allocation implications for the community has a very respectable pedigree. ... By admitting claims of discrimination [under the HRA] in respect of enactments, however, Parliament has made available a cause of action and a forum in which such claims may be publicised and to some degree vindicated, if not actually remedied. In other words, the legislation manifestly admits [such] claims.

190 Palmer "The Bill of Rights Fifteen Years On", above n 42, at [38]. 
Zealand judiciary to develop a national jurisprudence on these rights, as they have done for the CPR set out in the NZBORA.

\section{E Summary}

There is no compelling justification for the omission of ESCR from the NZBORA. Conversely, their inclusion in that instrument would provide a necessary and express restraint on Government's power. It would also be consistent with ESCR's status as fundamental human rights. ${ }^{191}$

\section{CONCLUSION}

Contrary to the New Zealand Government's current position, the common law and existing legislation do not provide sufficient protection for ESCR in New Zealand. While politicians should be primarily responsible for social and economic policy, the experiences of the 1980s and 1990s demonstrate that there is a role for the judiciary. What appear to be violations of ESCR have occurred in New Zealand, and New Zealanders should have been able to test these apparent violations in court. They should now be expressly empowered to take proceedings in respect of any future Government action or omission which appears ESCR-inconsistent.

New Zealand has recognised ESCR as fundamental human rights in the international sphere, and ESCR have no inherent defect which means that they cannot be recognised domestically as justiciable rights. The most obvious way for this to occur is to incorporate them into the NZBORA. If CPR are not to be left to politics (or to trust), neither should ESCR.

191 For an argument against recognising ESCR as fundamental human rights (including that they are "inimical to a free society" and incompatible with the right to property), see Bernard Robertson "Economic, Social and Cultural Rights: Time For A Reappraisal" (September 1997) New Zealand Business Roundtable $<$ www.nzbr.org.nz>. For a critique of some of the positions taken by Robertson, see Opie, above n 1, at 3132 and 211-214. 